\title{
OPEN Geochemical characterization and assessment of fluoride sources in groundwater of Siloam area, Limpopo Province, South Africa
}

\author{
Tobiloba Onipe ${ }^{1}$, Joshua N. Edokpayi ${ }^{1 \bowtie}$ \& John O. Odiyo ${ }^{1,2}$
}

Siloam's groundwater is reportedly characterized by high fluoride. In response to the reported high incidence of dental fluorosis in the area, sources of elevated fluoride in the groundwater were investigated. Total fluoride (TF) was determined using lon Chromatograph and Fluoride lon Selective Electrode. The mineral composition of rocks and soils were determined using $X$-ray Fluorescence and $X$-ray diffraction, respectively. Results revealed that groundwater fluoride concentration ranged from 3.92 to $4.95 \mathrm{mg} / \mathrm{L}$. Na-Cl water type was found to be dominant in the water samples. TF content of the rocks and soils ranged from 10 to $2000 \mathrm{mg} / \mathrm{L}$. Leachates were obtained by making a slurry from the samples at a predetermined temperature and time. TF in leachates ranged between 0.27 and $14.88 \mathrm{mg} / \mathrm{L}$ and 0.05 to $10.40 \mathrm{mg} / \mathrm{L}$ at induced, and non-induced temperatures, respectively. The possible source of fluoride has been previously inferred to be caused by fluorite minerals occurring at greater depth. However, this study proves that fluoride decreases with depth and the elevated fluoride in the groundwater is caused by smectite-kaolinite clay, muscovite and chlorite minerals abundant in the area. Geothermal temperature exhibited by the groundwater in the area is a major factor enhancing the release of fluoride from the clay materials.

Water is an important basic resource necessary for human development and economic growth. The supply of clean and safe water over the last decade has improved progressively globally ${ }^{1}$. Despite this recorded success, millions of people are not connected to water supply infrastructure and often resort to several alternative sources for their domestic water needs ${ }^{2,3}$. One of such sources include the exploitation of groundwater ${ }^{4}$.

Groundwater is the largest deposit of freshwater on earth and is a dependable alternative source of water with more than $75 \%$ of African population depending on it for survival ${ }^{5}$. However, there are various misconceptions about groundwater that it is free from chemical contamination and pathogens owing to its aesthetic property. Over the years, studies have shown that groundwater is exposed to various chemical contaminants from natural geological processes and anthropogenic activities ${ }^{6-8}$. Groundwater are often exploited in the form of natural springs, wells and drilling of boreholes.

Several contaminants have been reported in the groundwater which are of potential risk to public health. Amongst which are the presence of elevated levels of arsenic, lead, cadmium, mercury, fluoride, nutrients and microorganisms ${ }^{9-11}$. Some of these contaminants are more linked to geogenic sources than others. Fluoride is believed to be caused majorly by fluoride bearing minerals with little or no contribution from human activities. However, groundwater contamination from lead, nutrients and microorganisms are more linked to anthropogenic activities such as mining and agriculture ${ }^{10,11}$.

Fluoride is very important in the healthy development of the skeletal and dental framework of the body, if present in levels $<0.5 \mathrm{mg} / \mathrm{L}$, can lead to dental caries while concentration exceeding $1.5 \mathrm{mg} / \mathrm{L}$ can lead to fluorosis and no fluorosis diseases. The levels of fluoride vary globally and various climatic, hydrological and geochemical properties often determine and influence its levels in groundwater. The consumption of fluoride rich water has been linked to various public health burden notable among which are dental and skeletal fluorosis ${ }^{12-14}$. Cases of several non-fluorosis diseases such as Alzheimer's disease, loss of mobility, infertility, hearing difficulty, retarded growth, low intelligence quotient and cancer have also been linked to the consumption of fluoride rich water ${ }^{9,15-20}$.

${ }^{1}$ Department of Hydrology and Water Resources, University of Venda, Private bag X5050, Thohoyandou 0950, South Africa. ${ }^{2}$ DVC: RICl, Vaal University of Technology, Vanderbiljpark, South Africa. ${ }^{\circledR}$ email: Joshua.Edokpayi@ univen.ac.za 


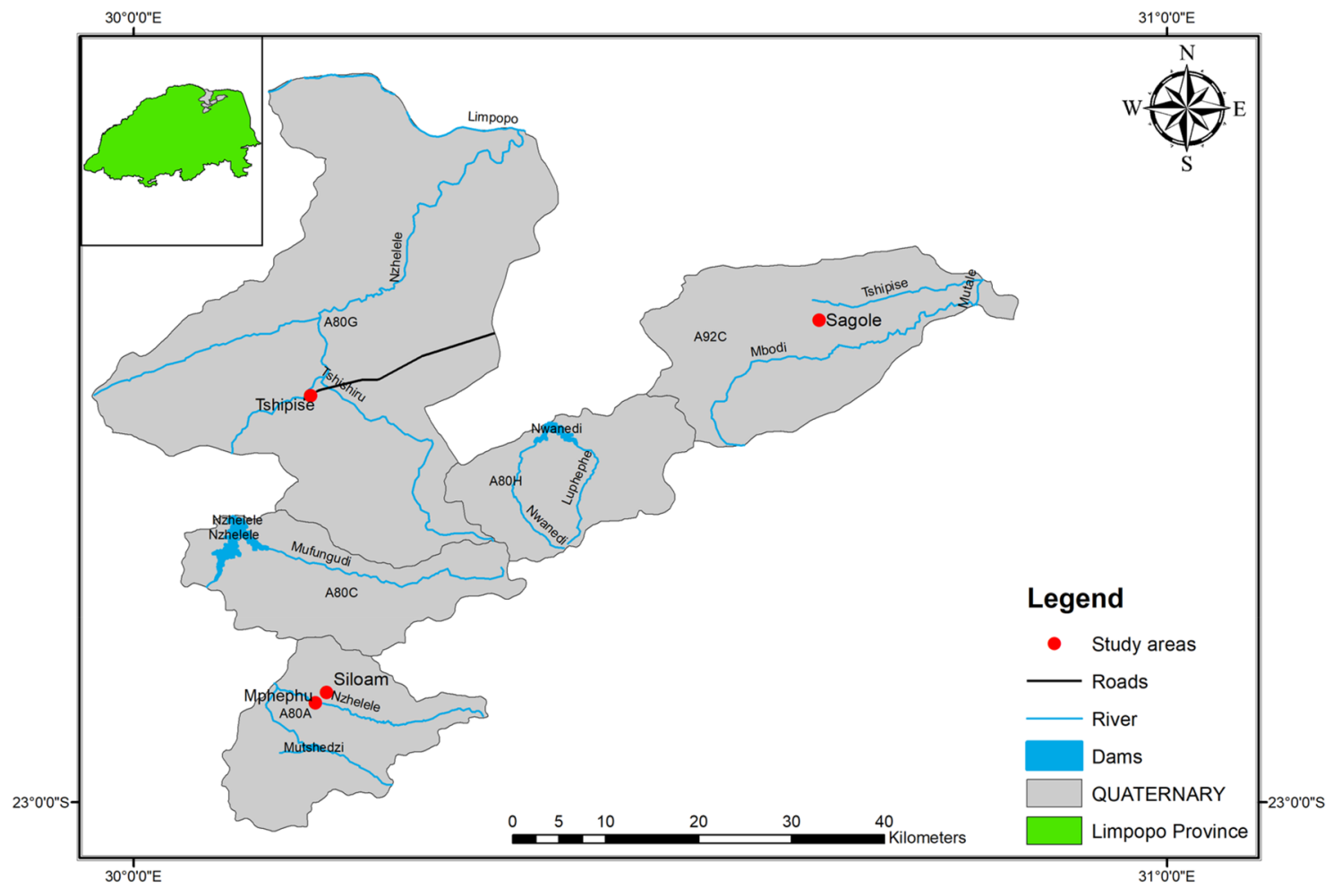

Figure 1. Map of the study area (Figure drawn using ArcGIS version 10.4, licensed to the University of Venda, South Africa).

Occurrence of elevated fluoride in groundwater is an emerging world-wide threat that affects over 200 million people worldwide and over 80 million people in East Africa ${ }^{21}$.

The occurrence of high levels of fluoride exceeding the permissible level of $1.5 \mathrm{mg} / \mathrm{L}$ by the World Health Organization has been recorded in many regions of the world. The East Africa rift valley system have been renowned for high levels of fluoride in groundwater ${ }^{22-24}$. In most parts of South Africa, elevated levels of fluoride have been reported in groundwater. The Northern region of the Limpopo Province which is semi-arid consist of numerous springs which are also known to contain high fluoride concentration ${ }^{9,25,26}$.

Globally, several efforts have been channeled towards the monitoring of groundwater quality for compliance to regulatory standard due to the number of people that depends on it for survival ${ }^{27-29}$. Fluoride compliance study have been greatly reported in literature ${ }^{7,8,26}$. However, very few studies have reported the source of fluoride in groundwater ${ }^{9,18,25}$. The most important factor controlling the occurrence of fluoride naturally in groundwater is the rock types (geology) of the area. Fluorine has been reported in all the major rock types (igneous, sedimentary and metamorphic $)^{9,18}$. Notable geogenic sources that have been reported include fluoride bearing minerals such as fluorite, villiaumite, apatite, biotite, amphibole, micas, topaz, cryolite, muscovite and fluorspar ${ }^{9,18,25,30,31}$.

In Siloam and the Northern part of South Africa, studies from our research group and other researchers have shown the occurrence of elevated fluoride concentrations in wells, boreholes (cold and hot) and geothermal springs $^{25,26,31-34}$. Siloam area is known for a large-scale occurrence of dental fluorosis amongst children and adults and according to Odiyo and Makungo ${ }^{35}$, over $85 \%$ of the population in the study area could be affected by dental fluorosis. The groundwater chemistry of this region has not been fully explored or reported. Therefore, in this study, we report mainly on the occurrence of fluoride bearing minerals in the region and some factors that could favor its dissolution.

\section{Description of the study area}

Location. The study area (Fig. 1) is located within Makhado Municipality, Vhembe District in Limpopo Province of South Africa. This includes the northern flank of Tswime Mountain where Mphephu thermal spring is located. It is $60 \mathrm{~km}$ northeast of Makhado and is approximately $45 \mathrm{~km}$ west of Thohoyandou. Siloam falls under surface water and groundwater quaternary catchment A80A of the Nzhelele River catchment, which is in the northern region of Limpopo Province, South Africa ${ }^{36}$. The Nzhelele River flows in the northwest direction, towards Nzhelele $\mathrm{Dam}^{26}$. The prevailing seasons are winter and summer, with average winter temperatures ranging between 16 and $22{ }^{\circ} \mathrm{C}$ and average summer temperatures varies between 22 to $40{ }^{\circ} \mathrm{C}^{37}$. Siloam experiences seasonal rainfall, ranging from $350-400 \mathrm{~mm}$ per annum in the summer months of September to March ${ }^{36,38}$. Rainfall in Siloam is largely influenced by its position on the leeward side of Soutpansberg mountain which plays an important role in the groundwater recharge of the area ${ }^{35}$. Evaporation rate is higher than the precipitation rate at $1300-1400 \mathrm{~mm} /$ annum. Siloam is dominated by two major geothermal springs and other hot private and 


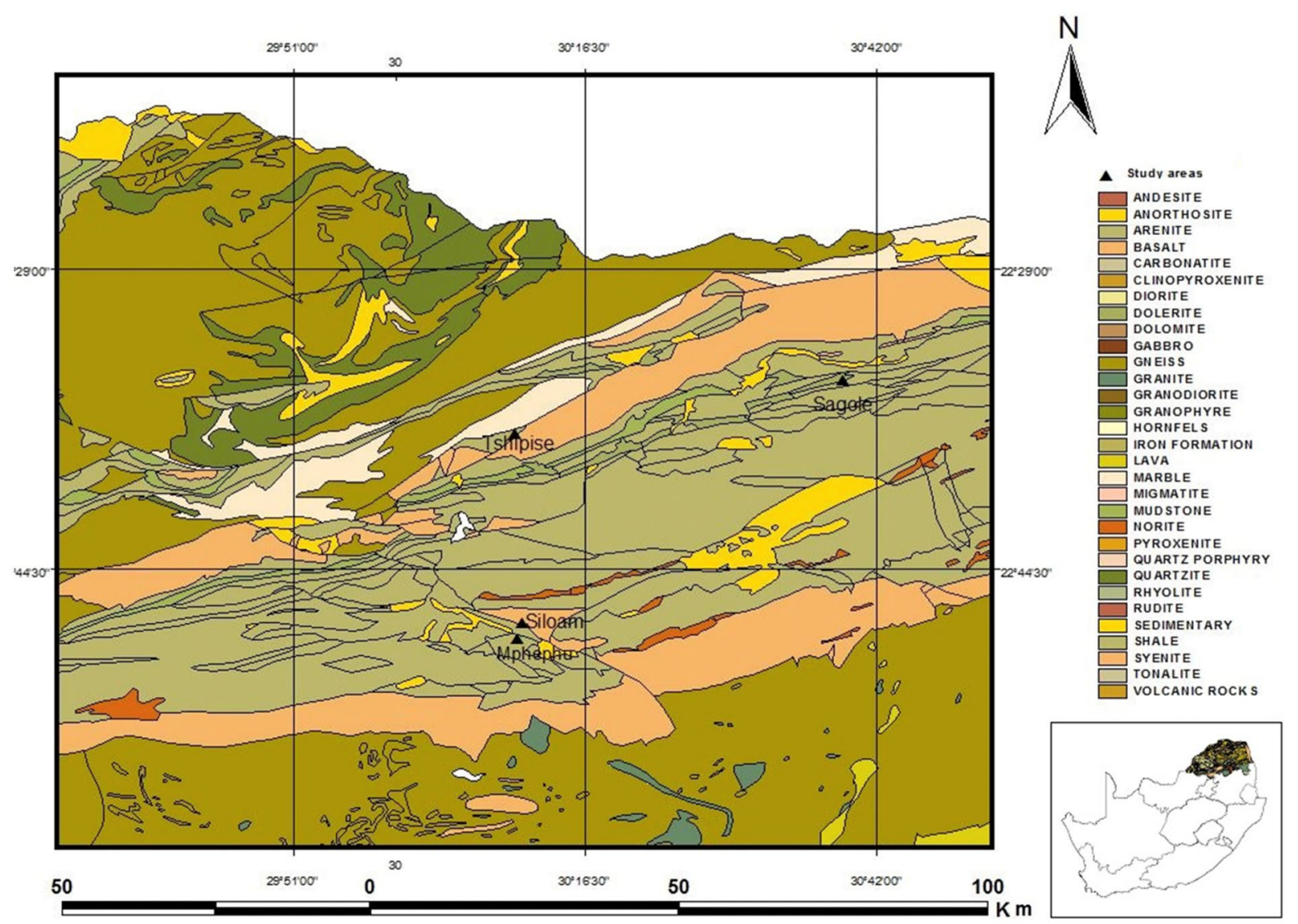

Figure 2. Geological map of the study $\operatorname{area}^{32}$, permission granted by Dr. Durowoju).

community borehole. Boreholes in the study area varies in depth and are usually within the range of 65-85 m and the mean depth to groundwater is about $15-25 \mathrm{~m}^{33}$.

Geology. Siloam lies within the Soutpansberg group (Fig. 2). Soutpansberg group is a Mokolian age extensively faulted succession that provides a link between the pre-and post-Bushveld age (younger than 1800 mya) rocks ${ }^{39}$. The Soutpansberg succession is an east to west trending asymmetrical rift overlying the Palala shear belt $^{39}$. Soutpansberg group is subdivided into six formations namely: Tshifhefhe formation, Sibasa formation, Fundudzi formation, Wyllie's formation, Musekwa formation and Nzhelele formation ${ }^{40,41}$. The Palala shear belt separates the Kaapval craton in the South and the Limpopo belt in the North ${ }^{39}$. The area has been through different post-deposition tectonic and erosional activities. The evolution of Soutpansberg started with the deposition of basaltic lava as a result of volcanic activities, followed by the deposition of syn-rift sequence of sedimentary rock. The area was subjected to an extensive erosional period of non-deposition after which resistant sandstonequartzite was deposited ${ }^{42}$. Unconformable deposition of Karoo supergroup sediments occurred and altogether, went through the process of block-faulting ${ }^{43}$. The sequence is best developed from north of Siloam fault to Musekwa mountains ${ }^{44}$.

\section{Materials and methods}

Sampling of soil, water and rock. One soil and rock samples were collected from the surface in the study area while twelve borehole cuttings from the subsurface were sampled for analysis. Four water samples were collected across the area. The samples were collected using plastic cups as recommended by Harvey ${ }^{45}$. For each location, the samples were collected three times in a $1 \mathrm{~L}$ sampling bottle and were transported to the laboratory for analysis. As suggested by Weaver et $\mathrm{al}^{46}$, the bottles were pre-rinsed with the water to be sampled, to avoid cross contamination. The groundwater samples for anion analysis were preserved in a refrigerator at a temperature of $4{ }^{\circ} \mathrm{C}$ and analyzed within seven days of collection. However, the samples for cation and trace metals analysis were preserved with concentrated nitric acid. Table 1 below summarizes the sample types and number.

Measurement of basic water quality parameters. The $\mathrm{pH}$, electrical conductivity (EC) and temperature were measured insitu using a multimeter (Multi 340i/SET). The instrument was calibrated prior to measurement in adherence to the manufacturer's guideline. 


\begin{tabular}{|c|c|c|c|c|}
\hline Sample type & Sample ID & Depth (m) & Location & No of samples \\
\hline \multicolumn{5}{|l|}{ Water samples } \\
\hline Monitoring borehole 1 & $\mathrm{BH} 1$ & $>60$ & $\begin{array}{l}22^{\circ} 53^{\prime} 34.008^{\prime \prime} \mathrm{S} \\
30^{\circ} 11^{\prime} 47.22^{\prime \prime} \mathrm{E}\end{array}$ & 1 \\
\hline Monitoring borehole 2 & $\mathrm{BH} 2$ & $>60$ & $\begin{array}{l}22^{\circ} 53^{\prime} 38.148^{\prime \prime} \mathrm{S} \\
30^{\circ} 11^{\prime} 18.52^{\prime \prime} \mathrm{E}\end{array}$ & 1 \\
\hline Private Borehole 1 & H1 & $>60$ & $\begin{array}{l}22^{\circ} 53^{\prime} 39.43^{\prime \prime} \mathrm{S} \\
30^{\circ} 11^{\prime} 43.94^{\prime \prime} \mathrm{E}\end{array}$ & 1 \\
\hline Private Borehole 2 & $\mathrm{H} 2$ & $>60$ & $\begin{array}{l}22^{\circ} 53^{\prime} 43.39^{\prime \prime S} \\
30^{\circ} 11^{\prime} 32.98^{\prime \prime} \mathrm{E}\end{array}$ & 1 \\
\hline \multicolumn{5}{|l|}{ Rocks and soil samples } \\
\hline Surface Soil Sample & S1 & N/A & $\begin{array}{l}22^{\circ} 53^{\prime} 34.83^{\prime \prime} \mathrm{S} \\
30^{\circ} 11^{\prime} 45.56^{\prime \prime} \mathrm{E}\end{array}$ & 1 \\
\hline Surface Rock Sample 1 & SR2 & N/A & $\begin{array}{l}22^{\circ} 54^{\prime} 22.8^{\prime \prime} \mathrm{S} \\
30^{\circ} 10^{\prime} 44.0^{\prime \prime} \mathrm{E}\end{array}$ & 1 \\
\hline Surface Rock Sample 2 & SR3 & N/A & $\begin{array}{l}22^{\circ} 52^{\prime} 02.5^{\prime \prime} \mathrm{S} \\
30^{\circ} 12^{\prime} 09.7^{\prime \prime} \mathrm{E}\end{array}$ & 1 \\
\hline Borehole 1 Cuttings & $\mathrm{X}$ & $1-65$ & $\begin{array}{l}22^{\circ} 53^{\prime} 34.008^{\prime \prime} \mathrm{S} \\
30^{\circ} 11^{\prime} 47.22^{\prime \prime} \mathrm{E}\end{array}$ & 6 \\
\hline Borehole 2 Cuttings & $\mathrm{Y}$ & $1-40$ & $\begin{array}{l}22^{\circ} 53^{\prime} 38.148^{\prime \prime} \mathrm{S} \\
30^{\circ} 11^{\prime} 18.528^{\prime \prime} \mathrm{E}\end{array}$ & 6 \\
\hline
\end{tabular}

Table 1. Description of Sample types. N/A not available.

Major anions analysis. Groundwater samples were analyzed for major anions content (fluoride, nitrate, phosphate, bicarbonate) using an Ion Chromatograph (Dionex Model DX 500). Prior to analysis, the samples were filtered using $0.45 \mu \mathrm{m}$ syringe filter. The samples were placed in vails associated with an auto sampler ${ }^{1}$. The $\mathrm{EC}$ of the samples were below $500 \mu \mathrm{s} / \mathrm{cm}$ hence dilution was not done.

Trace elements analysis for groundwater and rock samples. Major cations in the acidified groundwater water samples were analyzed using Inductively coupled plasma optical emission spectrophotometer (ICPOES) while Inductively coupled plasma mass spectrophotometer (ICP-MS) were used for the analysis of trace metals. Similarly, Trace and major metals in the soil and rock samples were analyzed using the same analytical instruments outlined above after microwave digestion. The procedure reported by Pais and Jones ${ }^{47}$ for soil and rock sample digestion were adhered to. Briefly: The soil/rock samples were digested using a microwave digestion system (SR ISO 11,466: 1999). Approximately $1.0 \mathrm{~g}$ of pre-treated samples were digested with $9 \mathrm{~mL} \mathrm{HNO}_{3}$ and $1 \mathrm{~mL} \mathrm{H}_{2} \mathrm{O}_{2}$. The solutions were allowed to stay overnight at room temperature and then, placed in the microwave for $30 \mathrm{~min}$, followed by cooling. The solutions were diluted to $50 \mathrm{~mL}$ with distilled water.

Preparation of soil and rock samples. The rocks and soil samples for X-ray diffractometer (XRD) analyses were prepared according to the standardized PANalytical backloading system, which provides nearly random distribution of the particles, while the samples for X-ray fluorescence (XRF) were prepared as pressed powders ${ }^{48}$. The rock samples were split, washed, dried, crushed and pulverized. Splitting into chips was done by a hydraulic splitter after which the split chip was washed and treated with ultrasound wave to remove any loose impure particles. After washing, the samples were dried overnight in an oven to remove excess water introduced during washing of the samples. A jaw crusher was used to crush the samples which were further reduced to finer grain $(<40 \mu \mathrm{m}$ in diameter) by pulverizing them for about five (5) min using a Retsch RS 200 miller. The milled samples were transferred to a paper bag and oven dried at $110^{\circ} \mathrm{C}$ for $6 \mathrm{~h}$. After oven drying, the samples were further milled to less than $20 \mu \mathrm{m}^{48}$.

Samples for total fluoride in soil and rocks were prepared by weighing $0.2 \mathrm{~g}$ of the samples in a nickel crucible, $2 \mathrm{~g}$ of $\mathrm{CaCO}_{3}$ and $\mathrm{Na}_{2} \mathrm{O}_{2}$ was added, respectively. The mixture was fused manually to aid leaching, using a low flame bunsen burner in a fume box. Auto fusion was avoided to prevent burning of the nickel crucibles and ensure that $\mathrm{Na}_{2} \mathrm{O}_{2}$ does not get moist. $250 \mathrm{~mL}$ plastic beakers were pre-washed in a heated Eco bath using concentrated $\mathrm{HCl}$. The heated crucibles were transferred into $250 \mathrm{~mL}$ plastic beakers where $50 \mathrm{~mL}$ of de-ionized water and $8 \mathrm{~mL}$ of $\mathrm{HCl}$ were added ${ }^{49}$. The mixtures were covered with a plastic lid and placed on warm bath until the samples were leached out of the crucibles. The crucibles were washed with de-ionized water to make sure that all the leachate was removed from the crucibles. The solutions were transferred into $100 \mathrm{~mL}$ volumetric flask and diluted to mark. Blank was prepared by fusing $2 \mathrm{~g}$ of $\mathrm{CaCO}_{3}$ and $\mathrm{Na}_{2} \mathrm{O}_{2}$. The fused mixture was transferred into a $250 \mathrm{~mL}$ beaker and $100 \mathrm{~mL}$ of de-ionized water and $16 \mathrm{~mL}$ of concentrated $\mathrm{HCl}$ were added ${ }^{48}$. The mixture was allowed to leach out and the crucible was rinsed with distilled water. The leachate was transferred into a $200 \mathrm{~mL}$ volumetric flask and filled to mark with de-ionized water. Calibration was carried out using $0.1 \mathrm{ppm}, 1 \mathrm{ppm}$, $10 \mathrm{ppm}, 100 \mathrm{ppm}$ and $1000 \mathrm{ppm}$ fluoride standards. The standards, samples and blanks were all mixed in equal proportion with TISAB II in a 1:1 ratio.

Calibration of $\mathrm{pH}$ meter was done using buffers 6.00 and 4.00 . The Slope was $97.9 \%$ which fell within the recommended slope limit of 95 to $105 \%$. The $\mathrm{pH}$ of the samples and blanks were adjusted to 6.00 using $50 \%$ $\mathrm{NaOH}$ and $\mathrm{HCl}$. The $\mathrm{pH}$ was adjusted because at $\mathrm{pH}$ below 5 , hydrogen ions complex a portion of the fluoride 
ions, forming $\mathrm{HF}$ or $\mathrm{HF}_{2}$, which cannot be detected by the fluoride electrode ${ }^{49}$. Likewise, in a solution with $\mathrm{pH}$ above 9, the electrode responds to hydroxide ion as well as to fluoride ion giving an exaggerated reading. Samples for leachable fluoride in soil and rocks were prepared by mixing $10 \mathrm{~g}$ of the sample with $100 \mathrm{~mL}$ of distilled water at a ratio of 1:10. The samples were prepared in duplicate to ensure that each sample is represented under induced temperature and room temperature. The first set of samples were shaken in a warm bath at normal room temperature for $6 \mathrm{~h}^{48}$. The second set of samples were shaken in a warm bath at a temperature of $42{ }^{\circ} \mathrm{C}$. Because of the clay contents of the sample the mixture was centrifuged for $10 \mathrm{~min}$ at a speed of $3000 \mathrm{rpm}$. The centrifuged samples were decanted and filtered using a $9 \mathrm{~cm}$ filter paper. The resultant mixture was then further filtered using a $40 \mu \mathrm{m}$ syringe filter to ensure that all impurities that could block the IC column were removed. The EC of the samples were below $500 \mu \mathrm{s} / \mathrm{cm}$ hence dilution was not required.

Lithology and mineral phase identification. The minerals in the rocks and soil samples from Siloam were identified and quantified using X-ray diffraction method of analysis. The samples were analyzed using a PANalytical X'Pert Pro powder diffractometer in $\theta-\theta$ configuration with an X'Celerator detector and variable divergence and fixed receiving slits with Fe filtered Co-Ka radiation $(\lambda=1.789 \AA)$. The phases were identified using X'Pert Highscore plus software. The relative phase amounts (weight\%) were estimated using the Rietveld method (Autoquan Program). The angles of the peaks were used to identify the mineral phase while the intensities of the peaks indicated the abundance of each mineral ${ }^{50}$.

Total oxide analysis. The total rock and soil oxides were measured using X-ray Fluorescence analytical method. The ARL Perform'X Sequential XRF instrument with Uniquant software was used for the analyses ${ }^{51}$. The software analysed for all elements in the periodic Table between $\mathrm{Na}$ and $\mathrm{U}$, but only elements found above the detection limits were reported ${ }^{51}$. The intensities for all elements were corrected automatically for line interference and absorption effects due to all the other elements using the fundamental parameter method ${ }^{49}$.

Total fluoride analysis. Total fluoride analysis were performed on the groundwater samples as well as the leached samples from rocks and soil. The groundwater analysis was carried out using Fluoride Ion-Selective electrode Orion Versastar Advanced Electrochemistry meter, while the fluoride in solids were analyzed using Metrohm fluoride meter with reference electrode ${ }^{48}$. Calibration standards $0.1 \mathrm{ppm}, 1 \mathrm{ppm}, 10 \mathrm{ppm}$ and $100 \mathrm{ppm}$ were used to calibrate the equipment. Orion TISAB II was used as the ionic strength adjustment buffer and the TISAB II was mixed in equal volume of $50 \mathrm{~mL}$ with $50 \mathrm{~mL}$ of samples and buffer. The TISAB used were premixed with standard at ratio 1:1. Labotec Magnetic stirrer was used to ensure that the mixture of TISAB and sample was thorough and accurate during measurement.

Leaching experiment. A form of mini-leaching experiment was used to determine the leachability of fluoride and other major cation and anions from the rocks and soil samples. Ion chromatography (IC) method was used for the analysis of both normal samples and the temperature induced samples. The IC was stabilized for 15 min prior to analysis ${ }^{48}$. The eluent used was Dionex AS22 which is made up of $45 \mathrm{mM} \mathrm{Na}_{2} \mathrm{CO}_{3}$ and $1.4 \mathrm{mM}$ $\mathrm{NaHCO}_{3}$. The $\mathrm{pH}, \mathrm{EC}$ and alkalinity of the water, soil and rock samples were pre-measured using Mantech Titrasip Autotitrator to ensure that the unknown samples fall within the recommended $\mathrm{pH}$ and EC limit for using Ion chromatograph ${ }^{1}$. The analysis was carried out using Dionex Model DX 500 Ion Chromatograph.

Statistical analysis. Experimental data were analyzed using the Statistical Package for Social Sciences (SPSS) (IBM Version 22) and Microsoft Excel 2013 (Microsoft Corp., Santa Rosa, CA). Descriptive statistics using tables, charts and graphs were used to present the chemical analysis data of the groundwater. Data recorded from the geochemical processes were subjected to Piper chart to identify the main chemical compositions of the groundwater. Correlation analysis was performed using a suitable package in SPSS.

\section{Results and discussion}

Fluoride levels in groundwater samples of the study area. Fluoride levels in the groundwater samples ranged between 3.92-4.95. These levels exceeded the South African National standards (SANS) for drinking water and the guidelines $(1.5 \mathrm{mg} / \mathrm{L})$ of the ${ }^{52,53}$. The levels recorded can lead to dental and skeletal fluorosis on the consumers of this waters and they are also at risk of non-fluorosis diseases. Previous studies by Odiyo and Makungo $^{35}$ have reported fluoride levels in the range of $1.7-5.6 \mathrm{mg} / \mathrm{L}$. Similarly, a more recent publication by the authors also reported fluoride levels exceeding $1.5 \mathrm{mg} / \mathrm{L}$. Table 2 presents the fluoride levels results of this study and other related studies on groundwater around the study area.

$\mathrm{pH}$ levels in groundwater of the study area. The $\mathrm{pH}$ of all the samples were in the range of 8.10-9.19 and complied with the South African (2014) National Standards for drinking water of 5.0 to 9.5. The samples with higher temperature $\left(45-48^{\circ} \mathrm{C}\right)$ in this study recorded slightly higher $\mathrm{pH}(8.86-9.10)$ than those with a lower temperature $\left(25-27^{\circ} \mathrm{C}\right)$ but this difference was not statistically significant $(\mathrm{p}>0.05)$. Odiyo and Makungo ${ }^{35}$ reported $\mathrm{pH}$ levels in the range of 6.9-8.7 for groundwater around Siloam area. Durowoju et al. ${ }^{32}$ reported mean pH levels between 7.89 and 9.39 for geothermal springs in Siloam, Tshipise, Mpephu and Sagole areas of Northern Limpopo province. High groundwater $\mathrm{pH}$ is a proxy indicator of long residence time of groundwater-rock interaction $^{54,55}$. Although $\mathrm{pH}$ affects fluoride mineralization differently, it is widely reported that alkaline $\mathrm{pH}$ favors the dissolution of fluoride from most fluoride bearing minerals ${ }^{9,25}$. Previous results on the monitoring of fluoride in the groundwater of Vhembe district in Limpopo Province shows the prevalence of alkaline $\mathrm{pH}^{26,32}$. In 


\begin{tabular}{|c|c|c|c|c|c|c|c|}
\hline Sample code & $\begin{array}{l}\text { Groundwater } \\
\text { type }\end{array}$ & Study location & Fluoride (mg/L) & pH & $\begin{array}{l}\text { Temperature } \\
\left({ }^{\circ} \mathrm{C}\right)\end{array}$ & $\mathrm{Ca}(\mathrm{mg} / \mathrm{L})$ & Reference \\
\hline $\mathrm{H} 1$ & Borehole & Siloam & $4.55 \pm 0.00$ & $8.86 \pm 0.01$ & $48.00 \pm 0.01$ & $3.54 \pm 0.01$ & This study \\
\hline $\mathrm{H} 2$ & Borehole & Siloam & $4.95 \pm 0.01$ & $9.19 \pm 0.06$ & $45.00 \pm 0.00$ & $0.82 \pm 0.00$ & This study \\
\hline BH1 & Borehole & Siloam & $4.50 \pm 0.00$ & $8.17 \pm 0.00$ & $25.00 \pm 0.01$ & $27.80 \pm 1.71$ & This study \\
\hline BH2 & Borehole & Siloam & $3.92 \pm 0.01$ & $8.10 \pm 0.01$ & $27.00 \pm 0.00$ & $12.80 \pm 0.61$ & This study \\
\hline BH3 & Borehole & Siloam & $5.60 \pm 0.85$ & $8.97 \pm 0.49$ & $\mathrm{Nr}$ & $0.33 \pm 0.71$ & $\begin{array}{l}\text { Odiyo and } \\
\text { Makungo }^{33}\end{array}$ \\
\hline BH4 & Borehole & Siloam & $5.76 \pm 0.55$ & $8.26 \pm 0.40$ & $\mathrm{Nr}$ & $0.08 \pm 0.07$ & $\begin{array}{l}\text { Odiyo and } \\
\text { Makungo }^{33}\end{array}$ \\
\hline BH5 & Borehole & Siloam & $3.37 \pm 1.56$ & $7.54 \pm 0.18$ & $\mathrm{Nr}$ & $0.47 \pm 0.46$ & $\begin{array}{l}\text { Odiyo and } \\
\text { Makungo }^{33}\end{array}$ \\
\hline BH6 & Borehole & Siloam & $1.51 \pm 0.12$ & $7.34 \pm 0.27$ & $\mathrm{Nr}$ & $1.41 \pm 1.25$ & $\begin{array}{l}\text { Odiyo and } \\
\text { Makungo }^{33}\end{array}$ \\
\hline BH7 & Borehole & Siloam & $1.44 \pm 0.18$ & $7.17 \pm 0.13$ & $\mathrm{Nr}$ & $1.04 \pm 0.71$ & $\begin{array}{l}\text { Odiyo and } \\
\text { Makungo }^{33}\end{array}$ \\
\hline BH8 & Borehole & Siloam & $1.49 \pm 0.06$ & $7.44 \pm 0.44$ & $\mathrm{Nr}$ & $1.62 \pm 2.43$ & $\begin{array}{l}\text { Odiyo and } \\
\text { Makungo }^{33}\end{array}$ \\
\hline BH9 & Borehole & Siloam & $5.59 \pm 0.16$ & $8.11 \pm 0.35$ & $\mathrm{Nr}$ & $0.07 \pm 0.02$ & $\begin{array}{l}\text { Odiyo and } \\
\text { Makungo }^{33}\end{array}$ \\
\hline BH10 & Borehole & Siloam & $5.37 \pm 0.48$ & $8.62 \pm 0.47$ & $\mathrm{Nr}$ & $0.07 \pm 0.06$ & $\begin{array}{l}\text { Odiyo and } \\
\text { Makungo }^{33}\end{array}$ \\
\hline BH11 & Borehole & Siloam & $4.25 \pm 0.90$ & $7.30 \pm 0.30$ & $\mathrm{Nr}$ & $2.95 \pm 2.58$ & $\begin{array}{l}\text { Odiyo and } \\
\text { Makungo }^{33}\end{array}$ \\
\hline BH12 & Borehole & Siloam & $2.21 \pm 1.24$ & $7.35 \pm 0.16$ & $\mathrm{Nr}$ & $1.81 \pm 1.65$ & $\begin{array}{l}\text { Odiyo and } \\
\text { Makungo }^{33}\end{array}$ \\
\hline BH13 & Borehole & Siloam & $5.11 \pm 0.49$ & $7.44 \pm 0.22$ & $\mathrm{Nr}$ & $1.30 \pm 0.68$ & $\begin{array}{l}\text { Odiyo and } \\
\text { Makungo }^{33}\end{array}$ \\
\hline BH14 & Borehole & Siloam & $5.10 \pm 1.09$ & $8.70 \pm 0.33$ & $35.30 \pm 1.53$ & $4.40 \pm 2.42$ & $\begin{array}{l}\text { Odiyo and } \\
\text { Makungo }^{35}\end{array}$ \\
\hline BH15 & Borehole & Siloam & $1.70 \pm 0.60$ & $6.90 \pm 0.01$ & $26.90 \pm 0.64$ & $70.40 \pm 13.59$ & $\begin{array}{l}\text { Odiyo and } \\
\text { Makungo }^{35}\end{array}$ \\
\hline GS1 & $\begin{array}{l}\text { Geothermal } \\
\text { spring }\end{array}$ & Siloam & $5.50 \pm 0.35$ & $8.40 \pm 0.15$ & $63.86 \pm 18.19$ & $2.40 \pm 0.86$ & $\begin{array}{l}\text { Odiyo and } \\
\text { Makungo }^{35}\end{array}$ \\
\hline GS2 & $\begin{array}{l}\text { Geothermal } \\
\text { spring }\end{array}$ & Siloam & $6.51 \pm 0.08$ & $9.39 \pm 0.06$ & $67.7 \pm 1.68$ & $5.69 \pm 0.05$ & Durowoju et al. ${ }^{32}$ \\
\hline GS3 & $\begin{array}{l}\text { Geothermal } \\
\text { spring }\end{array}$ & Mphepu & $3.43 \pm 1.25$ & $8.10 \pm 0.05$ & $42 \pm 1.12$ & $12.05 \pm 0.14$ & Durowoju et al. ${ }^{32}$ \\
\hline GS4 & $\begin{array}{l}\text { Geothermal } \\
\text { spring }\end{array}$ & Tshipise & $5.50 \pm 0.36$ & $8.47 \pm 0.22$ & $55 \pm 2.24$ & $2.81 \pm 0.09$ & Durowoju et al. ${ }^{32}$ \\
\hline GS5 & $\begin{array}{l}\text { Geothermal } \\
\text { spring }\end{array}$ & Sagole & $1.69 \pm 0.59$ & $8.38 \pm 0.93$ & $43.60 \pm 1.79$ & $2.28 \pm 3.36$ & Durowoju et al..$^{32}$ \\
\hline
\end{tabular}

Table 2. Mean fluoride, $\mathrm{pH}$, temperature and calcium levels of groundwater in the study area. $\mathrm{Nr}$ not reported.

this study, high fluoride levels were also associated with alkaline $\mathrm{pH}$ values. A Pearson's correlation analysis performed on the data in Table 2 between fluoride and $\mathrm{pH}$ yielded a positive correlation with $\mathrm{R}^{2}=0.72$. This shows that alkaline $\mathrm{pH}$ could have contributed to the mineralization of fluoride from their host rocks.

Temperature levels in groundwater of the study area. The mean temperature ranged from 25 to $48{ }^{\circ} \mathrm{C}$. Generally, temperature has a direct effect on chemical reactions as it speeds up the rate of chemical reaction and dissolution. Fluoride concentration was higher in hot water aquifer ( $\mathrm{H} 1$ and $\mathrm{H} 2)$ than in cold water aquifer (BH1 and $\mathrm{BH} 2)$. At $\mathrm{H} 1$ and $\mathrm{H} 2$, the temperature of the groundwater was $45^{\circ} \mathrm{C}$ and $48{ }^{\circ} \mathrm{C}$ yielding fluoride concentrations of $4.55 \mathrm{mg} / \mathrm{L}$ and $4.95 \mathrm{mg} / \mathrm{L}$, respectively, whereas lower levels of fluoride ( 4.50 and $3.92 \mathrm{mg} / \mathrm{L}$ ) were determined at groundwater temperatures of $27^{\circ} \mathrm{C}$ and $25^{\circ} \mathrm{C}$, respectively. The temperature change of $23{ }^{\circ} \mathrm{C}$ resulted in $1.03 \mathrm{mg} / \mathrm{L}$ increase in fluoride concentration in groundwater. This is a significant increase in fluoride concentration. A similar trend was reported in Ethiopia by Tekle-Haimanot et al. ${ }^{56}$, where $80 \%$ of the groundwater samples obtained in the geothermal springs of the rift valley area contained fluoride concentrations above $3.0 \mathrm{mg} / \mathrm{L}$ and $30 \%$ contained fluoride concentrations above $13.0 \mathrm{mg} / \mathrm{L}$ compared to the cold springs in the same area with maximum fluoride concentration of $<3.0 \mathrm{mg} / \mathrm{L}$. High geothermal temperature causes an increased dissolution of fluoride bearing minerals and thus increases the fluoride concentration in groundwater ${ }^{35}$. However, existence of geothermal springs does not necessarily mean fluoride will always be high. Therefore, water chemistry and local geology also plays an important role in the occurrence of high groundwater fluoride in any area. A positive correlation $\left(\mathrm{R}^{2}=0.6\right)$ was computed between fluoride and temperature from the data presented in Table 2.

Previous studies conducted within the region have also reported varying temperatures. Temperature in the range of $26.9-63.86^{\circ} \mathrm{C}$ have been reported for boreholes in Siloam area ${ }^{35}$. Durowoju et al..$^{32}$ reported temperatures 


\begin{tabular}{|c|c|c|c|c|c|}
\hline \multirow{2}{*}{$\begin{array}{l}\text { Parameters } \\
(\mathrm{mg} / \mathrm{L})\end{array}$} & \multicolumn{4}{|c|}{ Sampling sites } & \multirow[b]{2}{*}{ WHO (2011) } \\
\hline & H1 & $\mathrm{H} 2$ & BH1 & BH2 & \\
\hline $\mathrm{NO}_{3}^{-}$ & 0.17 & 1.31 & 3.22 & 83.95 & 44.0 \\
\hline $\mathrm{Cl}^{-}$ & 153.30 & 38.90 & 80.14 & 103.23 & 250 \\
\hline $\mathrm{SO}_{4}^{2-}$ & 16.45 & 10.55 & 17.56 & 25.88 & 500 \\
\hline $\mathrm{PO}_{4}^{3-}$ & 1.15 & 1.52 & 3.29 & 4.59 & N/A \\
\hline $\mathrm{CO}_{3}{ }^{2-}$ & 1.80 & 2.40 & 0.00 & 2.70 & 20.0 \\
\hline $\mathrm{HCO}_{2}^{-}$ & 8.54 & 9.76 & 31.11 & 15.86 & N/A \\
\hline $\mathrm{Na}^{+}$ & 118.00 & 62.70 & 124.00 & 170.00 & 400 \\
\hline $\mathrm{K}^{+}$ & 2.73 & 2.21 & 5.15 & 4.67 & 400 \\
\hline $\mathrm{Mg}^{2+}$ & $\mathrm{Bdl}$ & $\mathrm{Bdl}$ & 15.80 & 3.72 & 100 \\
\hline TDS & 306.00 & 130.00 & 296.00 & 423.00 & 450.00 \\
\hline $\mathrm{EC}(\mu \mathrm{S} / \mathrm{m})$ & 63.00 & 33.00 & 69.00 & 73.00 & 150.00 \\
\hline
\end{tabular}

Table 3. Chemical parameters of groundwater. STD N/A Not available, $H 1$ \& $H 2$ individual borehole $1 \& 2$, $B H 1$ \& $B H 2$ monitoring borehole $1 \& 2, B d l$ Below detection limit.

between 41.3-67.7 in thermal springs around the study area. Kirkpatrick ${ }^{57}$ reported higher fluoride levels in Malawi which were associated with higher geothermal temperature. His report shows that higher fluoride levels $\left(17 \mathrm{mg} / \mathrm{L}\right.$ and $20 \mathrm{mg} / \mathrm{L}$ ) were determined at 65 and $79^{\circ} \mathrm{C}$ when compared to $3-12 \mathrm{mg} / \mathrm{L}$ recorded within the temperature range of $32-54^{\circ} \mathrm{C}$. Results from several other studies agrees that geothermal temperature generally leads to more fluoride mineralization in groundwater ${ }^{14,23}$.

Influence of calcium on fluoride levels in groundwater. In this study, Ca varied differently in the sites (Table 2). Generally, the sites $\mathrm{H} 1$ and $\mathrm{H} 2$ with the lowest $\mathrm{Ca}$ concentration recorded the highest fluoride level. Although BH2 recorded lower Ca levels, the fluoride level was lower than that of BH1. It has been widely reported that low calcium concentration in groundwater often increases the dissolution of $\mathrm{CaF}_{2}$ which increases fluoride levels in groundwater ${ }^{26,33}$. Chae et al. ${ }^{58}$ stated that there is a thermodynamic relationship between $\mathrm{Ca}^{2+}$ and $\mathrm{F}^{-}$ions which is controlled by the equilibrium of fluorite. Odiyo and Makungo ${ }^{35}$ reported an inverse relationship between fluoride and calcium levels in groundwater around Siloam. A negative correlation $\left(\mathrm{R}^{2}=-0.30\right)$ was computed between fluoride and calcium levels in the groundwater of the study area reported in Table 2.

Nezli et al. ${ }^{59}$ however reported that when there is groundwater saturation with respect to fluorite, low calcium levels in groundwater can yield high fluoride concentrations. Odiyo and Makungo ${ }^{33}$ reported a mean level of calcium in the range of $0.38-1.44 \mathrm{mg} / \mathrm{L}$ associated with high levels of fluoride $(1.34-6.74 \mathrm{mg} / \mathrm{L}$ ) from 10 borehole samples from Siloam area. The chemistry of the groundwater at Siloam partially agrees with the opposing factor of solubility between calcium and fluoride because it appears that geothermal temperature plays an important role in the inverse solubility trend between fluoride and calcium.

Sulphate, nitrate and electrical conductivity levels in groundwater samples. The levels of sulphate recorded in this study complied with the regulatory standards for drinking water. Similarly, the levels of sodium, potassium, chloride all complied with regulatory standards (Table 3 ).

Nitrate contamination is a growing problem and ingestion by infants can cause methemoglobinemia and death ${ }^{60,61}$. High concentration of nitrate in groundwater above the permissible limit of $44 \mathrm{mg} / \mathrm{L}$ is considered an indicator of anthropogenic pollution ${ }^{62}$. Nitrate source is mostly from septic tanks, pit latrines and fertilizers. The water table in well BH2 occurs at $28 \mathrm{~m}$ below the surface, and this makes it easy for infiltration of sewage from nearby pit latrines located less than $20 \mathrm{~m}$ uphill from the well. The nitrate levels of the other boreholes complied with the regulatory guideline limit.

The electrical conductivity (EC) and total dissolved solids (TDS) values for all the locations sampled within Siloam were within the recommended limits of $<150 \mu \mathrm{S} / \mathrm{m}$ and $<450 \mathrm{mg} / \mathrm{L}$, respectively ${ }^{52}$.

Geochemical classification of groundwater. Groundwater chemistry is directly linked to its quality therefore it is imperative to understand the complex geochemical processes occurring below the surface of the earth through different geochemical facies present. The Major cations $\left(\mathrm{Ca}^{2+}, \mathrm{Mg}^{2+}, \mathrm{Na}^{+}\right.$and $\left.\mathrm{K}^{+}\right)$were plotted against major anions $\left(\mathrm{SO}_{4}{ }^{2-}, \mathrm{HCO}_{3}{ }^{-}\right.$and $\left.\mathrm{Cl}^{-}\right)$on a piper trilinear diagram, to understand the water type dominant in the groundwater of Siloam (Fig. 3).

Piper diagram divides water into six basic types based on the dominating cation and anion. The divisions are: (1) $\mathrm{Ca}-\mathrm{HCO}_{3}$ type, (2) Na-Cl type, (3) $\mathrm{Ca}-\mathrm{Mg}-\mathrm{Cl}$ type, (4) $\mathrm{Ca}-\mathrm{Na}-\mathrm{HCO}_{3}$ type, (5) $\mathrm{Ca}-\mathrm{Cl}$ type, and (6) $\mathrm{Na}_{-} \mathrm{HCO}_{3}$ type ${ }^{63}$. From the piper diagram (Fig. 3), all the samples were plotted within the sodium chloride (Na-Cl) quadrant. Na-Cl water type is dominated by $\mathrm{Na}^{+}$and $\mathrm{Cl}^{-}$derived from $\mathrm{Na}-\mathrm{Cl}$ which could be linked to the underlying geology emanating from gneissic rocks. This water type is typical of marine and deeper ancient groundwater influenced by ion exchange. Although exceptions can be made in situations where dissolution factors like residence time, climate and rainfall, are not favorable for fluoride migration from the rock to groundwater as experienced in Eswatini Kingdom ${ }^{32}$. 


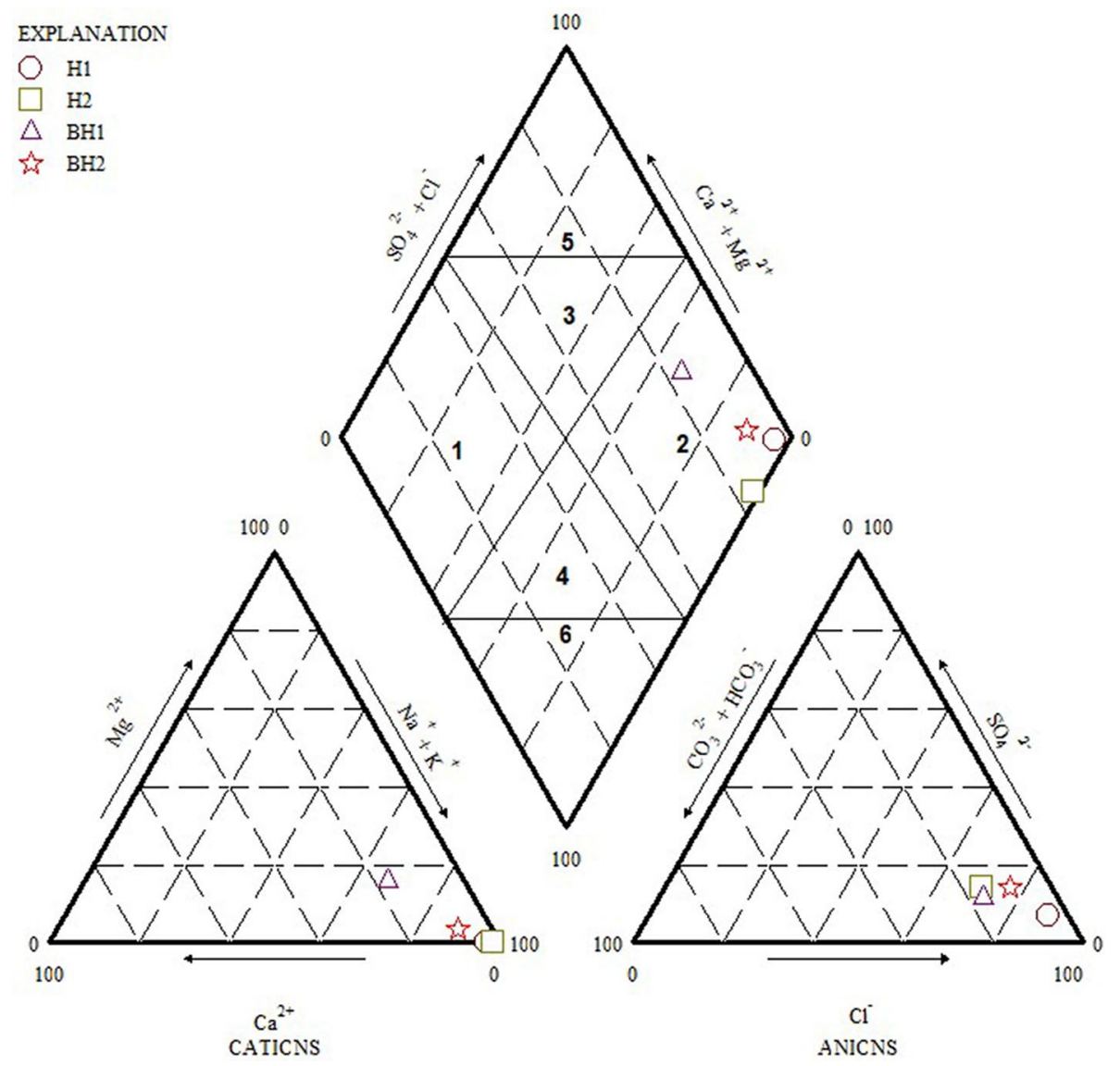

Figure 3. Piper Trilinear diagram of major anions and cations in Siloam groundwater (Figure drawn using GW Chart version 1.30: U.S. Geological Survey Software Release, 26 June 2020, https://doi.org/10.5066/P9Y29U1H).

A previous study based on the water type of thermal groundwaters around Siloam area indicated that the dominant water type is $\mathrm{Na}-\mathrm{Cl}^{26,32}$. Groundwater mixing from different sources do not occur in the study area because the water is predominantly and $100 \% \mathrm{Na}^{+}-\mathrm{Cl}^{-}$type. A piper plot by Durowoju ${ }^{64}$ shows that the geothermal springs of Siloam in both wet and dry periods were dominated by $\mathrm{Na}-\mathrm{Cl}$ ions. Therefore, seasonal changes do not significantly impact on the groundwater type and dominant cation and anions. However, groundwater with high fluoride in Korea occurs mostly within the basement aquifer and are dominantly $\mathrm{Na}-\mathrm{HCO}_{3}$ water type influenced by granitoids and metamorphic rocks ${ }^{58}$. Elevated $\mathrm{Na}^{+}$in groundwater could be from the weathering and dissolution of plagioclase tectosilicate mineral end member (albite). $\mathrm{Na}-\mathrm{Cl}$ water type indicates ancient groundwater with ample residence time with associated overburden and aquifer material.

Gibbs diagram was used to further buttress the source of the Na enrichment. The Gibbs diagram gave a clear indication that the groundwater enrichment was as a result of rock-water interaction and weathering (Fig. 4). The total dissolved solids were plotted against major anions and cations on Gibbs diagram to determine the geochemical process responsible for the chemical constituents of groundwater at Siloam using the Eqs. (1) and (2) ${ }^{65}$.

$$
\begin{aligned}
\text { Anions } & =\frac{\mathrm{Cl}}{\mathrm{Cl}+\mathrm{HCO}_{3}} \\
\text { Cations } & =\frac{\mathrm{Na}+\mathrm{K}}{\mathrm{Na}+\mathrm{K}+\mathrm{Ca}}
\end{aligned}
$$

However, the occurrence of $\mathrm{Cl}^{-}>\mathrm{Na}^{+}$hydro-chemical process in borehole $\mathrm{H} 1$ (Table 2) denotes that although the prevailing water type is $\mathrm{Na}^{+}-\mathrm{Cl}^{-}$, the dominance of the water type is as a result of ion exchange and reverse ion exchange. The occurrence of sulphate $\left(\mathrm{SO}_{4}{ }^{2-}\right)$ in groundwater is mostly assumed to be influenced by the dissolution of gypsum or the neutralization of acid water by limestone or dolomite ${ }^{66}$. Gibbs plot showed the geological process responsible for the mineralization process in the groundwater at Siloam.

The plot of $\mathrm{Na} / \mathrm{Cl}$ (Fig. 5) is a good indicator of the type of weathering responsible for the dominance of $\mathrm{Na}$ in groundwater. Mayback ${ }^{67}$ noted that $\mathrm{Na} / \mathrm{Cl}$ ratio greater than one is an indication of silicate weathering, otherwise the source of $\mathrm{Na}$ is from another source other than silicate weathering. From the $\mathrm{Na} / \mathrm{Cl}$ ratio plot, $75 \%$ of the samples $(\mathrm{BH} 2, \mathrm{BH} 1$ and $\mathrm{H} 2)$ show predominant silicate weathering while $25 \%(\mathrm{H} 1)$ of the samples show other sources of $\mathrm{Na}^{+}$other than silicate weathering. This other source is the reverse ion exchange. The dominant $\mathrm{Na}^{+}$ 

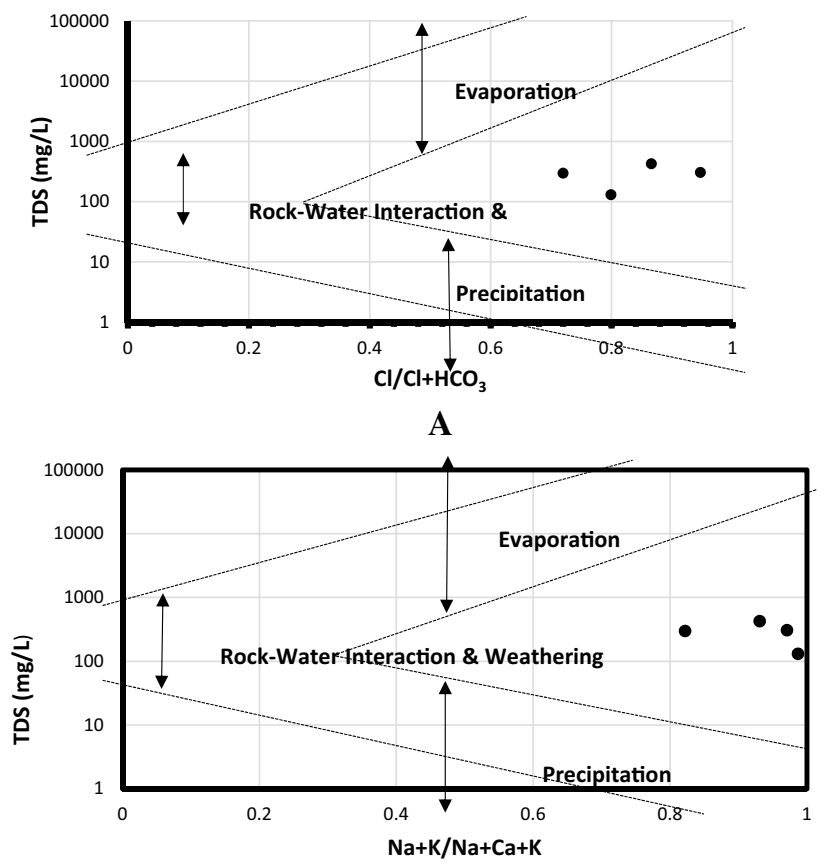

B

Figure 4. Gibbs plot showing dominant anion (A) and cation (B) mineralisation process of groundwater in Siloam.

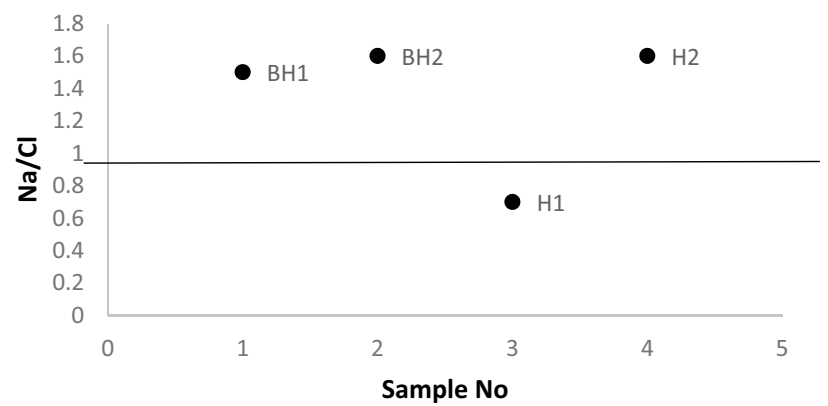

Figure 5. Plot showing $\mathrm{Na} / \mathrm{Cl}$ ratio.

in the groundwater at Siloam is thus as a result of the weathering and chemical alteration of tectosilicate minerals in the form of Plagioclase feldspar (Na rich feldspar) or sheet silicate minerals in the form of chlorite, due to rock-water interaction over a period resulting in base ion exchange between the rocks, soil and groundwater.

Chloro-Alkaline Indexes (CAI) were calculated from Eqs. (3) and (4) to determine if the $\mathrm{Na}^{+}$is from base ion exchange or from reverse ion exchange. In ion exchange process, the $\mathrm{Ca}$ and $\mathrm{Mg}$ from the groundwater is exchanged with the $\mathrm{Na}^{+}$and $\mathrm{K}^{+}$from the host rock or surrounding rocks. CAI 1 and CAI 2 were plotted in Fig. 6a,b.

$$
\begin{gathered}
\text { CAI } 1=\frac{\left[\mathrm{Cl}^{-}\left(\mathrm{Na}^{+}+\mathrm{K}^{+}\right)\right]}{\mathrm{Cl}} \\
\text { CAI } 2=\frac{\left[\mathrm{Cl}^{-}-\left(\mathrm{Na}^{+}+\mathrm{K}^{+}\right)\right]}{\mathrm{SO}_{4}^{2-}+\mathrm{HCO}_{3}^{-}+\mathrm{CO}_{3}^{2-}+\mathrm{NO}_{3}^{-}}
\end{gathered}
$$

CAI 1 and CAI 2 will result in a negative value if the process of $\mathrm{Na}^{+}$enrichment is by ion exchange process, otherwise, the process of reverse ion exchange is responsible ${ }^{68}$. CAI 1 and CAI 2 from Fig. 6 shows that the boreholes $\mathrm{BH} 1, \mathrm{BH} 2$ and $\mathrm{H} 2$ exhibited a sodium enrichment process by normal ion exchange while borehole $\mathrm{H} 1$ shows that the sodium enrichment process is by reverse ion exchange process. 

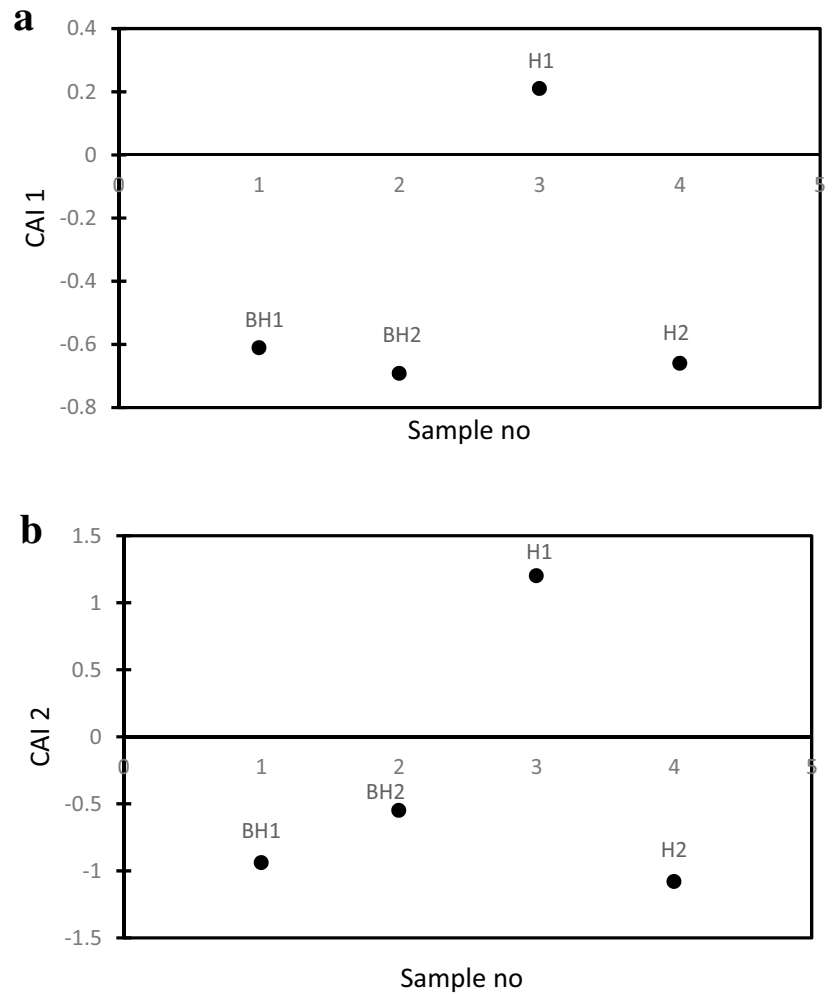

Figure 6. Chloro-Alkaline Index CAI 1 (a) and CAI 2 (b) for enrichment process.

Lithology and mineral composition of soils and rocks in the study area. The lithologic description of the samples is given in Table 4. Chlorite minerals can be found in any major rock group, but they are known to be predominant in low grade metamorphic rocks. Chlorite is also the index mineral for green schist facie $^{69}$. Chlorite is found as a common constituent of igneous rocks resulting from hydrothermal alteration of pyroxenes, amphiboles, biotite and garnet ${ }^{69}$. In sedimentary basins, Clay-rich sediments derived from the weathering of igneous rocks are often rich in chlorite ${ }^{69}$. This is basically the source of chlorite enrichment in sedimentary terrain.

The abundance of chlorite can be seen in Siloam which is made up of volcano sedimentary sequence. Table 5 gives the weight percent (wt.\%) and the constituent minerals in all the soil and rock samples collected in Siloam as analysed by X-ray Diffraction (XRD). The abundance of chlorite is seen especially in borehole cuttings of BH1 at depths $40-65 \mathrm{~m}$ where chlorite is seen as much as $38 \mathrm{wt} . \%$ of the total rock mass at some depths (Table 5). However, the occurrence of chlorite determines the colour of the total rock mass given that the wt.\% of chlorite is more than $20 \%$ as seen in cuttings X40 and X65 (Table 5). From depths 5-35 m in borehole BH1, the pink-brown colour could be due to the presence of smectite and occurrence of hematite. The brown colour may also be due to the presence of plagioclase.

However, occurrences of quartz and muscovite mostly do not determine the colour of the whole rock mass because they are mostly colourless to white in colour. The pinkish colour of rock SR2 could signify the occurrence of hematite (iron oxide). The occurrence of chlorite in the sedimentary terrains of Siloam and the high abundance of smectite and hematite group shows that the present geologic sequence has undergone a series of weathering and tectonic activities. This explains the abundance of $\mathrm{Na}^{+}$in groundwater at Siloam because of ion exchange and possible reverse ion exchange during the process of weathering of silicate minerals like plagioclase and chlorites.

From the mineralogy (Table 5), silicate minerals as well as clay minerals are abundant in the study area. The area is dominated by clay minerals such as chlorite and smectite, as well as silicate minerals such as muscovite, biotite and plagioclase. Clay can adsorb and desorb fluoride under favorable condition. Clay in the soil can functions as a natural barrier to protect groundwater from fluoride pollution due to its strong adsorption potential ${ }^{70}$. The adsorption capabilities of clay are possible in the acidic $\mathrm{pH}$ conditions. However, the adsorbed fluoride ion can also be released into the groundwater under alkaline conditions.

The adsorption properties of fluoride by clay are proportional to the amount of clay minerals present. Clay desorption is a faster geochemical process when compared to adsorption process ${ }^{71}$, thus it is easy for fluoride to migrate from clay to groundwater when in contact with small volume of alkaline water. The abundance of clay minerals show that extensive weathering altered the chemical and physical composition of the silicate minerals to form clay minerals. The fluoride enrichment of the groundwater in the area is as a result of ion exchange between the fluoride bearing minerals and groundwater. However, muscovite also contains fluoride as an accessory ion in its chemistry, which at favorable conditions, is released into the groundwater. 


\begin{tabular}{|c|c|c|c|c|c|}
\hline Location & Sample ID & Depth (M) & Associated group & Lithology & Brief description \\
\hline \multirow{3}{*}{ S } & S1 & & Soil & Clay & Brown color with very fine texture \\
\hline & SR2 & & Metamorphic & Epitomized grey wacke & $\begin{array}{l}\text { This rock type shows a low-grade metamorphism } \\
\text { characteristic and it exhibits an aphanitic texture. It has a green colour due to the abun- } \\
\text { dance of chlorite }\end{array}$ \\
\hline & SR3 & & Sedimentary & Sandstone & Pinkish Sandstone due to the presence of hematite \\
\hline \multirow{5}{*}{ BH1 } & $\mathrm{X} 5$ & 5 & Sedimentary & Argillaceous Sediment & $\begin{array}{l}\text { Topsoil with brittle texture and pinkish-brown color. Presence of Smectite and hematite } \\
\text { noticeable }\end{array}$ \\
\hline & $\mathrm{X} 15$ & 15 & Sedimentary & Argillaceous Sediment & Dark brown color with reduced pinkness probably due to the hematite content \\
\hline & $\mathrm{X} 20$ & 20 & Sedimentary & Argillaceous Sediment & Light pink color due to the heavy presence of clay mineral Smectite and Hematite \\
\hline & $\mathrm{X} 30$ & 30 & Sedimentary & Argillaceous Sediment & $\begin{array}{l}\text { Reduction in the pink color and traces of darker brown color. Smectite and Hematite still } \\
\text { present although at a reduced concentration }\end{array}$ \\
\hline & $\mathrm{X} 40$ & 40 & Sedimentary & Gray Wacke & $\begin{array}{l}\text { Green in color probably due to the presence of Chlorite mineral and the rock is slightly } \\
\text { saturated due to its function being the aquifer rock. Total disappearance of clay minerals of } \\
\text { smectite and hematite }\end{array}$ \\
\hline \multirow{7}{*}{ BH2 } & $\mathrm{X} 65$ & 65 & Sedimentary & Gray Wacke & $\begin{array}{l}\text { Green in color probably due to the presence of Chlorite mineral and the rock is slightly } \\
\text { saturated due to its function being the aquifer rock. Total disappearance of clay minerals of } \\
\text { smectite and hematite noticeable. Index mineral noticed are quartz and chlorite }\end{array}$ \\
\hline & Y5 & 5 & Soil & Clay & Light brown in color with more than $60 \mathrm{wt} . \%$ Smectite \\
\hline & Y10 & 10 & Soil & Clay & Light brown color with increased smectite content of more than $70 \mathrm{wt. \%}$ \\
\hline & $\mathrm{Y} 20$ & 20 & Soil & Clay & $\begin{array}{l}\text { Reduced lightness with two different groups of Smectite namely smectite } 1 \text { and } 2 . \text { Overall } \\
\text { smectite content is greater than } 75 \text { wt.\% }\end{array}$ \\
\hline & Y25 & 25 & Soil & Sandy Clay & $\begin{array}{l}\text { Dark brown color with intercalation of clay and sand. Although smectite content is still } \\
\text { above } 50 \% \text { but there is reduction in its wt.\% }\end{array}$ \\
\hline & Y28 & 28 & Igneous & Basalt & Dark color with dominantly plagioclase feldspar and diopside mineral \\
\hline & Y40 & 40 & Igneous & Basalt & Dark color with dominantly plagioclase feldspar and diopside mineral \\
\hline
\end{tabular}

Table 4. Lithologic Description of Sampled Rocks and Soils. $S$ surface soil, SR surface rocks, BH1 borehole 1, BH2 borehole 2 .

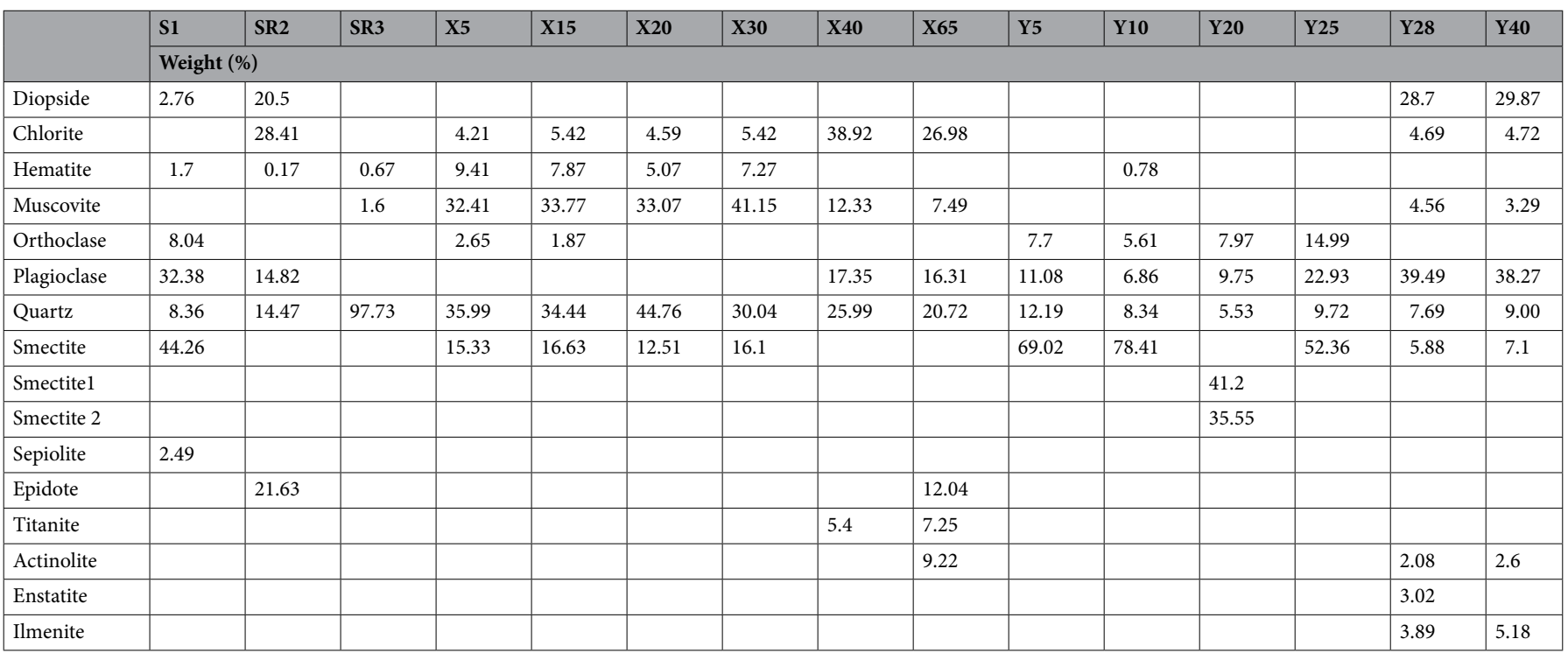

Table 5. Mineral constituents and percentage weight of rocks and soils. $S$ surface soil, $S R$ surface rock, $X$ borehole $\mathrm{BH} 1$ depth, $Y$ borehole $\mathrm{BH} 2$ depth

Muscovite is an important fluoride bearing mineral because it contains fluorine in its crystal lattices and hydroxyl groups which can also substitute for fluoride because of their similar ionic charges ${ }^{70}$. This fluorine can be released as fluoride ion into the groundwater under favorable conditions. Muscovite occurs at about 1.62 wt. $\%$ (Table 5) in SR3. Onipe ${ }^{48}$ noted that muscovite in the surface rocks at Siloam contributes to the groundwater fluoride rather than fluorite as earlier inferred by McCaffrey and Willis ${ }^{25}$ and Odiyo and Makungo ${ }^{35}$. Onipe ${ }^{48}$ also argued that the muscovite present in the surface sandstone at Siloam can never be the sole contributor of fluoride to groundwater of the area.

Surface rock SR2 contains high proportions of chlorite and epidote (Fig. 6). The occurrence of clinochlore, an end member of chlorite is predominant in Siloam. Chlorite has been linked to fluoride contribution to 


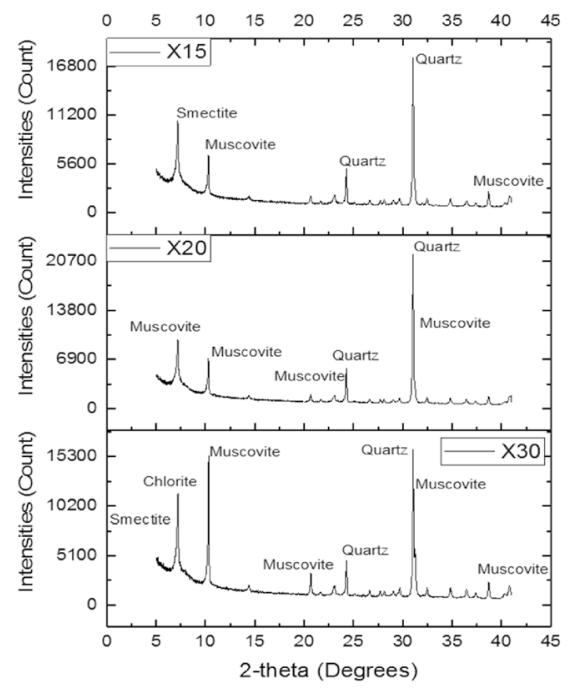

A

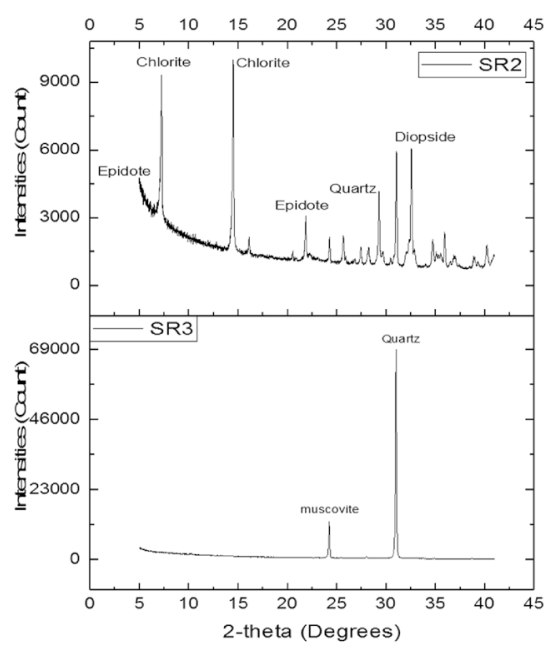

B

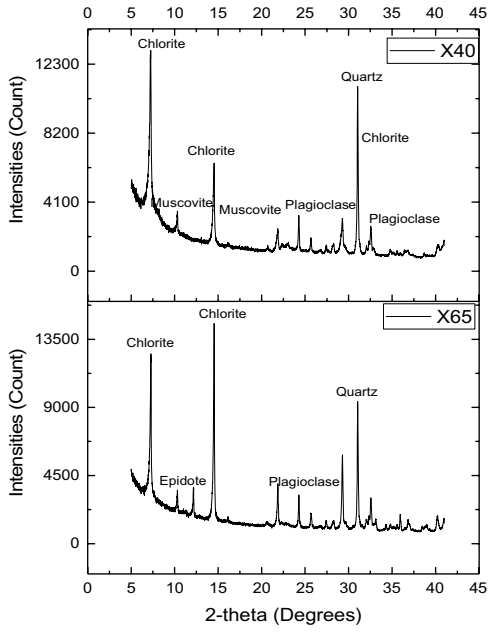

C

Figure 7. XRD plot showing major minerals in borehole 1 at X15, X20 \& X30 (A) and surface soil SR2 \& SR3 (B) borehole 1 at X40 and X65.

groundwater mostly due to its hydroxyl content which is displaced by fluoride ion. Generally, chlorite contains fluoride but not as much as its ripidolite. This reason is attributed to the fact that clinochlore has an appreciable number of aluminium in its octahedral layer therefore limiting its fluoride adsorption properties unlike ripidolite that has aluminium in its tetrahedral layer. However, at varying depth in borehole $\mathrm{BH} 1$, muscovite occurs as an abundant rock forming mineral rather than its accessory form as found in SR2. The concentration of muscovite in wt. \% increases from topsoil to $30 \mathrm{~m}$ below the surface (Table 5). The major minerals present in borehole $\mathrm{BH} 1$ from depth $5 \mathrm{~m}$ to $30 \mathrm{~m}$ are muscovite, quartz and smectite (Table 5). The abundance of major dominating minerals of borehole BH1 from depth $15-30 \mathrm{~m}$ are shown in Fig. 7. Fluorine affiliated muscovite increases with depth from 5 to $15 \mathrm{~m}$, slows down at depth $20 \mathrm{~m}$ and picks up its increasing trend again at depth $30 \mathrm{~m}$ below ground level before drastically reducing as the depth increases.

Figure 7C shows the XRD peaks for the epitomized gray-wacke which is the aquifer rock for borehole $\mathrm{BH} 1$. Although muscovite is present, the abundance is not as much as at depths 5 to $30 \mathrm{~m}$. The grey wacke is dominated by chlorite which explains why the color is greenish grey (Table 4). The primary minerals present in the rock materials include chlorite, quartz and plagioclase. The intensities and abundance of each mineral are identified in Fig. 7. The combined presence of muscovite and chlorite at depth X40 and X 65 in borehole BH1 may accounts for the slightly high total fluoride concentration of the aquifer due to the exchange of $\mathrm{OH}$ with $\mathrm{F}$ in their structure. Figure 7 also shows a high abundance of plagioclase which denotes that the level of weathering is either absent or low at depth $40 \mathrm{~m}$ below the earth surface, therefore there has been no chemical alteration of plagioclase to smectite clay or kaolin as seen at shallow depths before $40 \mathrm{~m}$. Two main dynamic geochemical processes occur in clay, they are the enrichment and leaching processes. Under the dynamic geochemical process of leaching, areas with clay formations and arid to semi-arid climatic conditions, experience high groundwater and surface water fluoride concentration ${ }^{72}$. Dynamic geochemical process of leaching occurs when fluoride is leached out of clay formation into groundwater through infiltration and percolation of water. Fluorine can easily migrate from clay formations to groundwater during migration of groundwater ${ }^{73}$.

In borehole $\mathrm{BH} 2$ at Siloam, muscovite which is the predominant fluoride bearing mineral in the area is seen to be absent until the depth of $28 \mathrm{~m}$ (Table 5). Muscovite occurrence was found at depth 28 to $40 \mathrm{~m}$ although at a volume less than $5 \mathrm{wt} . \%$. The peaks of smectite at depths Y5, Y10, Y15 and Y20 occur at almost the same count and intensity (Fig. 7). Smectite is the most abundant mineral at depths Y5-Y20. Clay could also act as a migration agent for fluoride enrichment of groundwater at Siloam. The abundance of major minerals in borehole $\mathrm{BH} 2$ at depths Y28 and Y40 are also described in Table 5. The abundance of chlorite and plagioclase were also revealed from the results. Y28 and Y40 is the basaltic aquifer material of borehole BH2.

Chemical composition of rocks and soils in the study area. In sedimentary terrain, the most abundant fluorine bearing mineral is associated with mica mineral group and clay minerals especially montmorillonite and kaolinite. Total rock chemistry is important to determine the total rock composition in oxides and elemental properties. The graphical representation of major oxides in the rocks and soil of Siloam are presented in Fig. 8. The rocks and soil are dominated by high silica content followed by aluminium oxides. The highest concentration of silica occurs at surface sandstone rock of location SR3. The formula for conversion of oxides to elemental weight. percent is given in Eq. (5). 


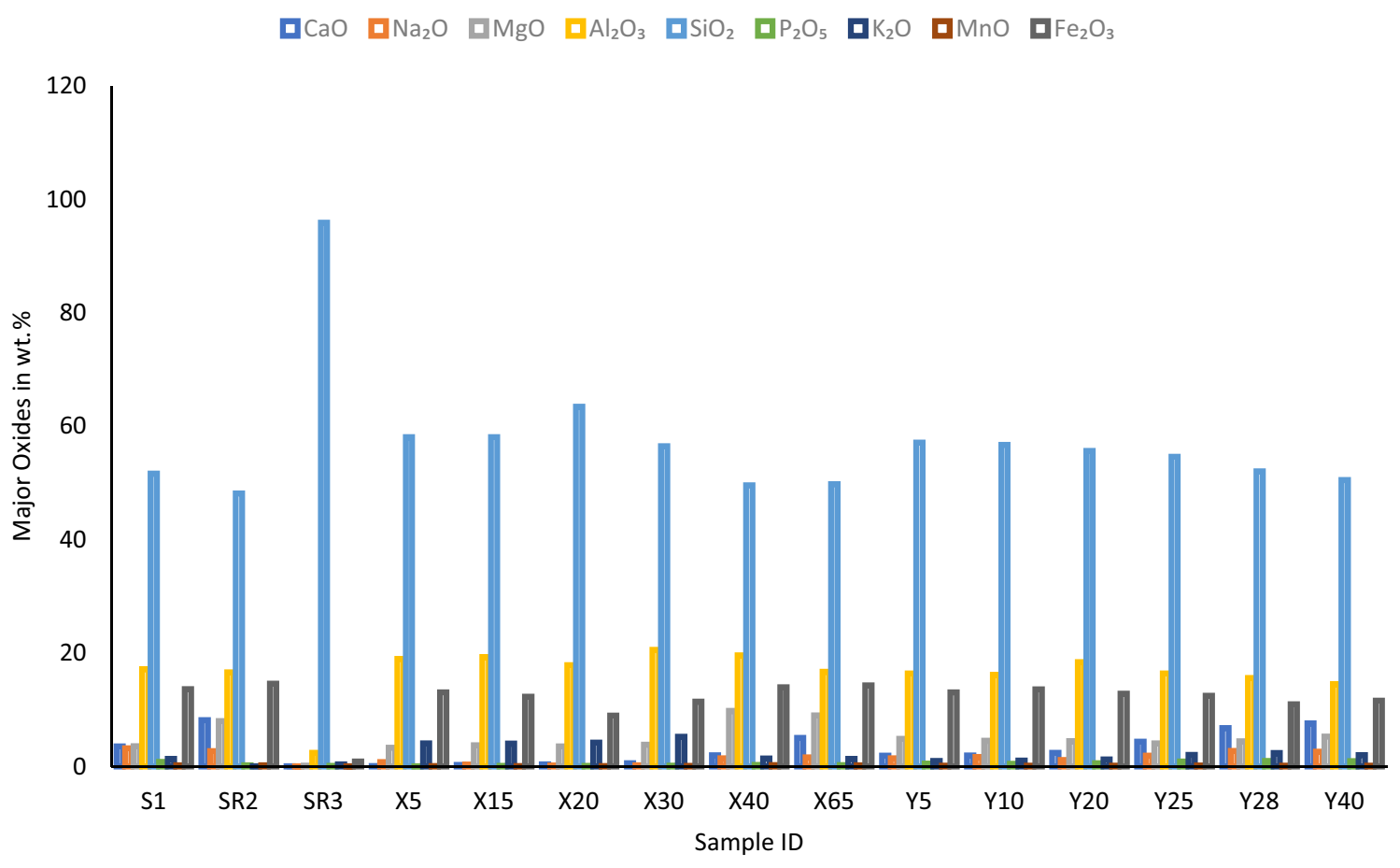

Figure 8. Major oxide abundance in sampled rocks and soils.

Oxide wt percent $\times$ Conversion factor $=$ Elemental wt percent

The conversion factor is the sum of the atomic weights of the elements in the required formula divided by the sum of the atomic weights in the original formula. Silica $\left(\mathrm{SiO}_{2}\right)$ and quartz $\left(\mathrm{SiO}_{2}\right)$ have the same chemical composition, but they are different in nature. Silica refers to the total pure silicon dioxide in the rock mass while quartz refers to a mineral with a very high concentration of silica. However, often, quartz occurs as silica with little amount of impurities. Therefore, the name is used interchangeably. Total rock silica could be from quartz and other silicate minerals like feldspars, chlorites and other aluminium and silicate rich minerals. $\mathrm{The}^{\mathrm{SiO}} \mathrm{O}_{2}$ refers to the total silica content of the rock and soil. Silica has the highest wt. \% in soils and rocks of Siloam. This means that the area is dominated by felsic rock and the soil with high silica content. Felsic rocks, which contain relatively high concentrations of $\mathrm{SiO}_{2}$, tend to have higher concentrations of fluorine than mafic rock ${ }^{74}$.

Table 6 shows the total major elemental and fluorine compositions of rocks and soils at Siloam in mg/kg. Although fluorine is regarded as a trace element, its concentration in some rocks and soil in Siloam is higher than expected. The total fluorine content of rocks and soil ranges from 10 to $2000 \mathrm{mg} / \mathrm{kg}$ (Table 6). The average fluorine concentration is about $762 \mathrm{mg} / \mathrm{kg}$. This is above the permissible limit of $30 \mathrm{mg} / \mathrm{kg}$ concentration of fluorine in soil for agriculture $\mathrm{e}^{75}$. The highest fluorine concentration of $2000 \mathrm{mg} / \mathrm{kg}$ occurs at a depth of $5 \mathrm{~m}$ in borehole BH2. The lowest concentration occurs in borehole BH1 at a depth of $30 \mathrm{~m}$ (Table 6).

The fluorine concentration in clay is typically in the range of $20-500 \mathrm{mg} / \mathrm{kg}^{76}$. The surface clay deposit S1 has a total fluorine concentration of $431 \mathrm{mg} / \mathrm{kg}$ (Table 6). However, the clay formation of borehole BH2 from $5 \mathrm{~m}$ to around $20 \mathrm{~m}$ depth has the highest concentrations of fluorine. The Soil of BH2 at depths $5 \mathrm{~m}$ and $10 \mathrm{~m}$ have more fluorine concentration than the surface rock formations and aquifer rocks in Siloam as observed from Table 6. This is different from the findings of McCaffrey and Willis ${ }^{25}$ that stated that rock samples have higher fluorine content than soil samples. The clay deposit and argillaceous sediments of Siloam are from chemical alteration and weathering of plagioclase of parent rock materials therefore giving more room for $\mathrm{OH}$ and $\mathrm{F}$ replacements. This ion displacement gives a higher room for more storage of fluoride in the crystal lattices of the resultant clay. It should be noted, however, that clays formed under hydrothermal conditions are mostly rich in fluoride ${ }^{77}$ as observed in Siloam, although this is not always the case as observed in Sagole, Tshipise and Evangelina area of Limpopo, South Africa ${ }^{78}$.

Fluoride leaching and other chemical constituents from rocks and soils. The fluoride concentration emigrating out of the rock and soil samples of Siloam ranges from 0.27 to $14.88 \mathrm{mg} / \mathrm{L}$ (Table 7). Leachate with the lowest fluoride concentration occurs at surface rock SR2 and leachate with the highest fluoride concentration occurs at a depth of $5 \mathrm{~m}$ of borehole BH2 (Table 7). Fluoride concentrations show a decreasing trend from the surface down to the aquifer. Figure 9 shows the fluoride concentration trend in the borehole BH1 leachates.

The fact that from boreholes $\mathrm{BH} 1$ and $\mathrm{BH} 2$, the sub-surface rocks and soils of Siloam show decreasing trends in fluoride concentrations, means that the aquifer rocks release less fluorine into the groundwater compared to the regolith and overburden soils and clays. This may partially be due to the loose state of the overburden. The ions in the leachate were correlated against each other to determine the relationship between them in relation to 


\begin{tabular}{|l|l|l|l|l|l|l|l|l|l|l|}
\hline Sample ID & Ca & Na & Mg & Al & Si & P & K & Mn & Fe & F \\
\hline S1 & $25,429.08$ & $23,889.18$ & $21,587.40$ & $90,880.81$ & $241,417.00$ & 3500.73 & $11,206.35$ & 1541.26 & $95,607.98$ & 431.00 \\
\hline SR2 & $58,286.88$ & $20,253.87$ & $48,240.00$ & $87,863.80$ & $225,241.50$ & 969.03 & 305.48 & 1657.43 & $101,972.52$ & 1400.00 \\
\hline SR3 & 415.72 & 242.60 & 940.68 & $12,650.27$ & $448,332.50$ & 484.52 & 3137.78 & 41.82 & 6329.57 & 160.00 \\
\hline X5 & 658.58 & 5749.73 & $20,019.60$ & $100,461.14$ & $271,477.25$ & 281.54 & $33,619.05$ & 569.26 & $91,551.46$ & 450.00 \\
\hline X15 & 2021.47 & 2559.56 & $22,672.80$ & $102,101.97$ & $271,617.50$ & 471.42 & $33,536.04$ & 723.38 & $86,096.14$ & 330.00 \\
\hline X20 & 2521.48 & 1409.61 & $21,406.50$ & $94,744.70$ & $296,628.75$ & 475.79 & $35,030.22$ & 749.72 & $62,806.12$ & 290.00 \\
\hline X30 & 4057.22 & 1468.96 & $23,215.50$ & $108,877.01$ & $264,231.00$ & 659.12 & $43,580.25$ & 836.46 & $79,941.42$ & 10.00 \\
\hline X40 & $14,143.14$ & $10,757.55$ & $59,094.00$ & $103,848.66$ & $231,926.75$ & 1169.82 & $11,621.40$ & 1773.61 & $97,706.18$ & 850.00 \\
\hline X65 & $36,000.72$ & $11,944.59$ & $54,330.30$ & $88,340.17$ & $232,815.00$ & 999.59 & $11,123.34$ & 1618.71 & $100,084.14$ & 770.00 \\
\hline Y5 & $13,500.27$ & $10,905.93$ & $29,486.70$ & $86,911.06$ & $267,129.50$ & 2330.91 & 8301.00 & 1184.99 & $91,551.46$ & 2000.00 \\
\hline Y10 & $13,785.99$ & $12,389.73$ & $27,376.20$ & $85,587.81$ & $265,166.00$ & 2099.57 & 8633.04 & 1239.20 & $95,188.34$ & 1500.00 \\
\hline Y20 & $17,143.20$ & 8457.66 & $26,954.10$ & $97,444.13$ & $260,163.75$ & 2549.16 & $10,210.23$ & 1215.97 & $89,872.90$ & 1200.00 \\
\hline Y25 & $31,214.91$ & $14,021.91$ & $24,602.40$ & $86,805.20$ & $255,442.00$ & 3727.71 & $17,017.05$ & 1394.10 & $87,145.24$ & 800.00 \\
\hline Y28 & $51,572.46$ & $20,847.39$ & $29,124.90$ & $82,041.50$ & $239,593.75$ & 4932.45 & $19,922.40$ & 1014.60 & $74,695.92$ & 620.00 \\
\hline Y40 & $54,429.66$ & $19,437.78$ & $31,959.00$ & $76,960.22$ & $236,181.00$ & 4234.05 & $16,851.03$ & 1177.24 & $81,340.22$ & 620.00 \\
\hline
\end{tabular}

Table 6. Major elemental compositions of rocks and soils $(\mathrm{mg} / \mathrm{kg})$ in the study area. $S$ surface soil, $S R$ surface rock, $X$ borehole $\mathrm{BH} 1$ depth, $Y$ borehole $\mathrm{BH} 2$ depth, ion units, $m g / k g$ depth: $\mathrm{m}$.

\begin{tabular}{|l|c|c|l|l|l|l|l|l|l|l|l|l|}
\hline \multirow{2}{*}{ Sample } & $\mathbf{K}$ & $\mathbf{E C}$ & $\mathbf{p H}$ & $\mathbf{C a}$ & $\mathbf{M g}$ & $\mathbf{C l}$ & $\mathbf{N O}_{\mathbf{3}}$ & $\mathbf{N O}_{2}$ & $\mathbf{P O}_{\mathbf{4}}$ & $\mathbf{N a}$ & $\mathbf{B}$ & $\mathbf{F}$ \\
\cline { 2 - 14 } & $\mathbf{m g} / \mathbf{k g}$ & $\mathbf{\mu s} / \mathbf{c m}$ & & $\mathbf{m g} / \mathbf{k g}$ & $\mathbf{m g} / \mathbf{k g}$ & $\mathbf{m g} / \mathbf{k g}$ & $\mathbf{m g} / \mathbf{k g}$ & $\mathbf{m g} / \mathbf{k g}$ & $\mathbf{m g} / \mathbf{k g}$ & $\mathbf{m g} / \mathbf{k g}$ & $\mathbf{m g} / \mathbf{k g}$ & $\mathbf{m g} / \mathbf{k g}$ \\
\hline S 1 & 62.50 & 24.00 & 7.57 & 135.00 & 891.00 & 36,03 & 1,65 & 0.00 & 1,89 & $\mathbf{9 2 9 . 0 0}$ & 1.75 & 10,52 \\
\hline SR 2 & 11.60 & 3.00 & 7.17 & BDL & 40.00 & 2,75 & 0,12 & 0.00 & 0,67 & 36.10 & 0.05 & 0,27 \\
\hline SR 3 & 27.80 & 3.00 & 6.83 & $\mathrm{BDL}$ & $\mathrm{BDL}$ & 2,77 & 0,21 & 0.00 & 3,17 & 2.26 & 0.04 & 0,44 \\
\hline X 5 & 379.00 & 42.00 & 7.10 & 19.80 & 773.00 & $\mathbf{1 1 4 , 4 3}$ & 24,66 & 0.00 & 1,55 & $\mathbf{1 0 2 0 . 0 0}$ & 2.07 & 3,85 \\
\hline X 15 & 125.00 & 7.00 & 6.91 & 2.26 & 172.00 & 10,59 & 2,41 & 0.00 & 0,78 & 110.00 & 0.46 & 2,29 \\
\hline X 20 & 118.00 & 3.00 & 6.95 & 1.88 & 150.00 & 2,15 & 0,60 & 0.00 & 0,65 & 52.40 & 0.28 & 1,10 \\
\hline X 30 & 164.00 & 3.00 & 7.03 & 11.90 & 183.00 & 1,61 & 0,72 & 0,03 & 0,59 & 35.90 & 0.38 & 0,78 \\
\hline X 40 & 33.40 & 4.00 & 7.16 & 18.20 & 179.00 & 1,43 & 0,58 & 0,13 & 0,30 & 72.00 & 0.26 & 0,68 \\
\hline X 65 & 31.90 & 9.00 & 7.37 & 36.30 & 41.20 & 2,34 & 0,56 & 0,71 & 0,50 & 82.40 & 0.02 & 0,53 \\
\hline Y 5 & 31.90 & 32.00 & 8.00 & 186.00 & 675.00 & 11,57 & 0,78 & 0.00 & 0,39 & $\mathbf{8 8 6 . 0 0}$ & 0.93 & 14,88 \\
\hline Y 10 & 45.60 & 76.00 & 7.97 & 145.00 & 438.00 & $\mathbf{1 7 1 , 7 9}$ & 8,10 & 0.00 & 1,00 & $\mathbf{1 6 2 0 . 0 0}$ & 1.11 & 9,51 \\
\hline Y 20 & 26.00 & 6.00 & 7.16 & 68.00 & 178.00 & 2,12 & 0,85 & 0.00 & 0,39 & 129.00 & 0.26 & 3,79 \\
\hline Y 28 & 61.90 & 9.00 & 7.43 & 94.80 & 97.90 & 1,93 & 0,29 & 0,33 & 0,90 & 151.00 & 0.15 & 1,02 \\
\hline Y 25 & 25.30 & 5.00 & 7.10 & 19.30 & 61.60 & 1,59 & 0,15 & 0,01 & 0,70 & 84.20 & 0.14 & 2,60 \\
\hline Y 40 & 54.50 & 10.00 & 7.50 & 110.00 & 104.00 & 2,46 & 0,27 & 0,49 & 0,80 & 166.00 & 0.17 & 0,72 \\
\hline
\end{tabular}

Table 7. Chemical parameters in the leachate obtained from leaching experiment. BDL Below detection Limit, $S$ surface soil, $S R$ surface rock, $X$ borehole BH1 depth, $Y$ borehole BH2 depth

the release of fluoride. Table 8 shows the correlation coefficients in the leachate at Siloam. Fluoride concentrations in groundwater of boreholes $\mathrm{BH} 1$ and $\mathrm{BH} 2$ show high positive correlations to $\mathrm{pH}, \mathrm{Ca}, \mathrm{Na}$ (Table 8).

This means that at an increasing F concentration, $\mathrm{pH}, \mathrm{Ca}$ and $\mathrm{Na}$ increases. The concentrations of these highlighted parameters $(\mathrm{pH}, \mathrm{Ca}, \mathrm{Na})$ are directly proportional to each other. $\mathrm{EC}$ is also positively correlated to $\mathrm{F}$, which means that increase in fluoride results in an increase in $\mathrm{pH}, \mathrm{Ca}$ and $\mathrm{Na}$ which in turn increases the conductivity of the groundwater of boreholes $\mathrm{BH} 1$ and $\mathrm{BH} 2$. The very weak correlation between fluoride and nitrate confirms that the possible source of high nitrate in groundwater of $\mathrm{BH} 2$ is not from a natural source rather from anthropogenic sources which were previously inferred.

The weak negative correlation between fluoride and potassium connotes that most of the occurrence does not originate from K bearing minerals. The groundwater fluoride of the study area is controlled by the desorption and adsorption properties of clay and partly by chlorite. Therefore, the groundwater hydrochemistry is dominated by $\mathrm{Na}-\mathrm{Cl}$ water type signifying the importance of $\mathrm{Na}$ weathering and dissolution to investigating groundwater fluoride source. The process is simplified by Eq. (6).

$$
\mathrm{NaAlSiO}_{8}+2 \mathrm{H}^{+}+9 \mathrm{HO} \rightarrow \mathrm{AlSiO}_{5}(\mathrm{OH})+4 \mathrm{HSiO}+2 \mathrm{Na}
$$

The hydroxyl ion in the clay is displaced by fluoride in the structure lattice of the kaolin-smectite clay due to the similarity in their charge and radius. The resultant $\mathrm{Na}$ in the equation explains the abundance of $\mathrm{Na}$ in 


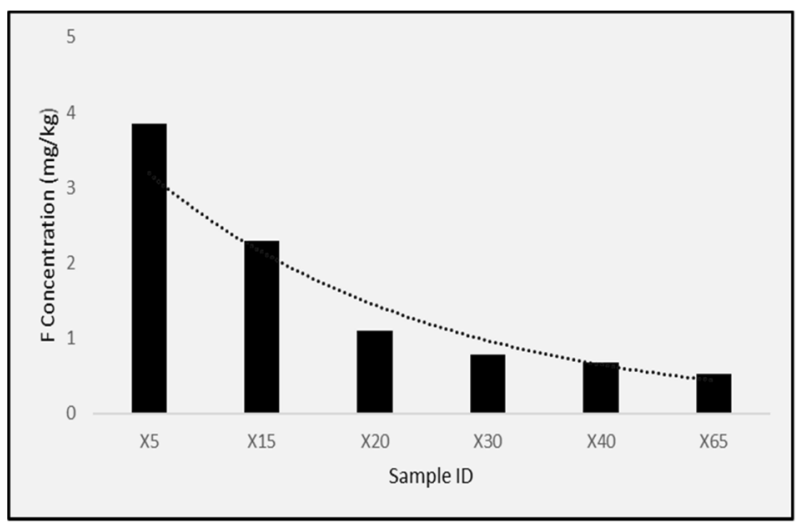

(a)

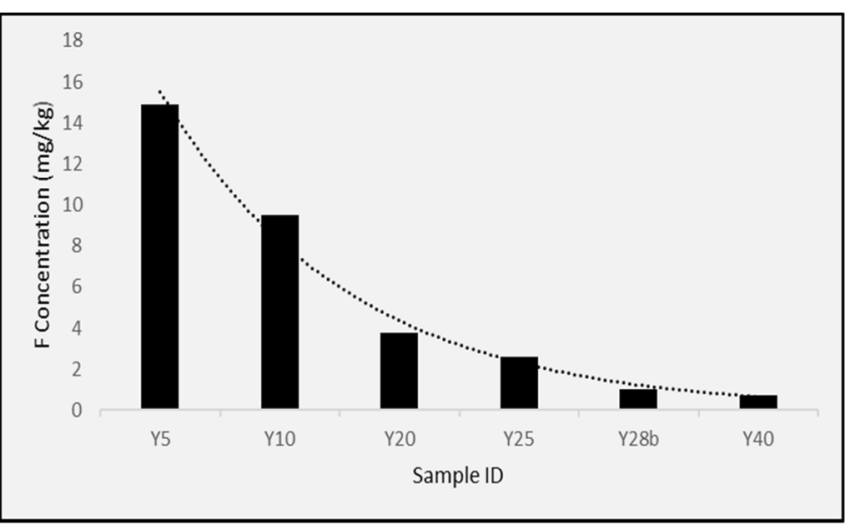

(b)

Figure 9. Fluoride concentration of (a) borehole 1 and (b) borehole 2.

\begin{tabular}{|c|c|c|c|c|c|c|c|c|c|c|c|c|}
\hline & $K$ & $E C$ & $p H$ & $C a$ & $M g$ & $\mathrm{Cl}$ & $\mathrm{NO}_{3}$ & $\mathrm{NO}_{2}$ & $\mathrm{PO}_{4}$ & $\mathrm{Na}$ & B & $F$ \\
\hline$K$ & 1.00 & & & & & & & & & & & \\
\hline$E C$ & 0.25 & 1.00 & & & & & & & & & & \\
\hline$p H$ & -0.27 & 0.69 & 1.00 & & & & & & & & & \\
\hline $\mathrm{Ca}$ & -0.26 & 0.60 & 0.94 & 1.00 & & & & & & & & \\
\hline$M g$ & 0.44 & 0.64 & 0.50 & 0.56 & 1.00 & & & & & & & \\
\hline $\mathrm{Cl}$ & 0.41 & 0.94 & 0.44 & 0.33 & 0.55 & 1.00 & & & & & & \\
\hline $\mathrm{NO}_{3}$ & 0.85 & 0.60 & 0.02 & -0.03 & 0.56 & 0.74 & 1.00 & & & & & \\
\hline $\mathrm{NO}_{2}$ & -0.20 & -0.19 & 0.17 & 0.09 & -0.35 & -0.24 & -0.21 & 1.00 & & & & \\
\hline $\mathrm{PO}_{4}$ & 0.15 & 0.11 & -0.22 & -0.09 & $\begin{array}{l}0.17 \\
\end{array}$ & 0.19 & 0.22 & -0.22 & 1.00 & & & \\
\hline $\mathrm{Na}$ & 0.26 & 0.97 & 0.72 & 0.67 & 0.80 & 0.89 & 0.59 & -0.27 & 0.15 & 1.00 & & \\
\hline$B$ & 0.62 & 0.70 & 0.36 & 0.39 & 0.95 & 0.70 & 0.76 & -0.37 & 0.27 & 0.82 & 1.00 & \\
\hline$F$ & -0.06 & 0.67 & 0.77 & 0.82 & 0.80 & 0.44 & 0.16 & -0.35 & 0.01 & 0.79 & 0.64 & 1.00 \\
\hline
\end{tabular}

Table 8. Correlation of physico-chemical constituent of leachates.

groundwater at Siloam. The study area is dominated by rocks of high silica content (Table 6). The silica content is a combined value of all the silicate minerals (quartz, plagioclase and muscovite). Rocks with high silica content often have high fluorine concentration ${ }^{74}$. This agrees with this study because there seem to be a decreasing trend in the fluorine content towards the mafic rocks at depth. Also, a decreasing trend could be noticed as opposed to a general norm that fluoride increases with depth. This is possibly due to the clay and argillaceous overburden. At $\mathrm{BH} 1$ and $\mathrm{BH} 2$, fluoride decreases from depth X5 to X65 and Y5 to Y40. This coincides with the decreasing concentration of smectite and chlorite in the mineralogy of the rocks.

Effect of temperature on fluoride release from soil and rocks. Siloam is located on Siloam fault which acts as a channel for transport of heated groundwater up to some near surface aquifer. This gives Siloam a very high geothermal gradient. Therefore, the effect of temperature is very important when investigating the source of fluoride from the dissolution of minerals irrespective of the temperature of the water at present. The effect of temperature in the dissolution of fluoride from the mineral constituents in the rocks and soil into the groundwater was experimented in the laboratory. The average water temperature of $42{ }^{\circ} \mathrm{C}$ from past literature focusing on Siloam was used as the base temperature. Although, the effect of temperature was simulated for less than $10 \mathrm{~h}$. Temperature plays an important role by increasing the fluoride concentration in the leachates. This difference can be observed in Fig. 10 where the comparison can be seen between fluoride release at room temperature and fluoride release at $40^{\circ} \mathrm{C}$.

The temperature effect can be seen at almost all sampling points except for Y28 (Fig. 10). The sampling point Y5 shows a distinct effect of temperature by a concentration difference of almost $5 \mathrm{mg} / \mathrm{L}$. The groundwater temperature is evident to be one of the driving factors favoring the dissolution of fluorine from the rocks and soils at Siloam, into the groundwater in the area.

\section{Conclusions}

Fluoride levels exceeding $1.5 \mathrm{mg} / \mathrm{L}$ recommended by the WHO was determined in the groundwater of the study area. The level is in the range that could cause both fluorosis and non-fluorosis diseases to the consumer of the groundwater resource. Positive correlation was determined between fluoride levels with $\mathrm{pH}$ and temperature while a negative correlation was determined with calcium. The major water type present in the study area is the 


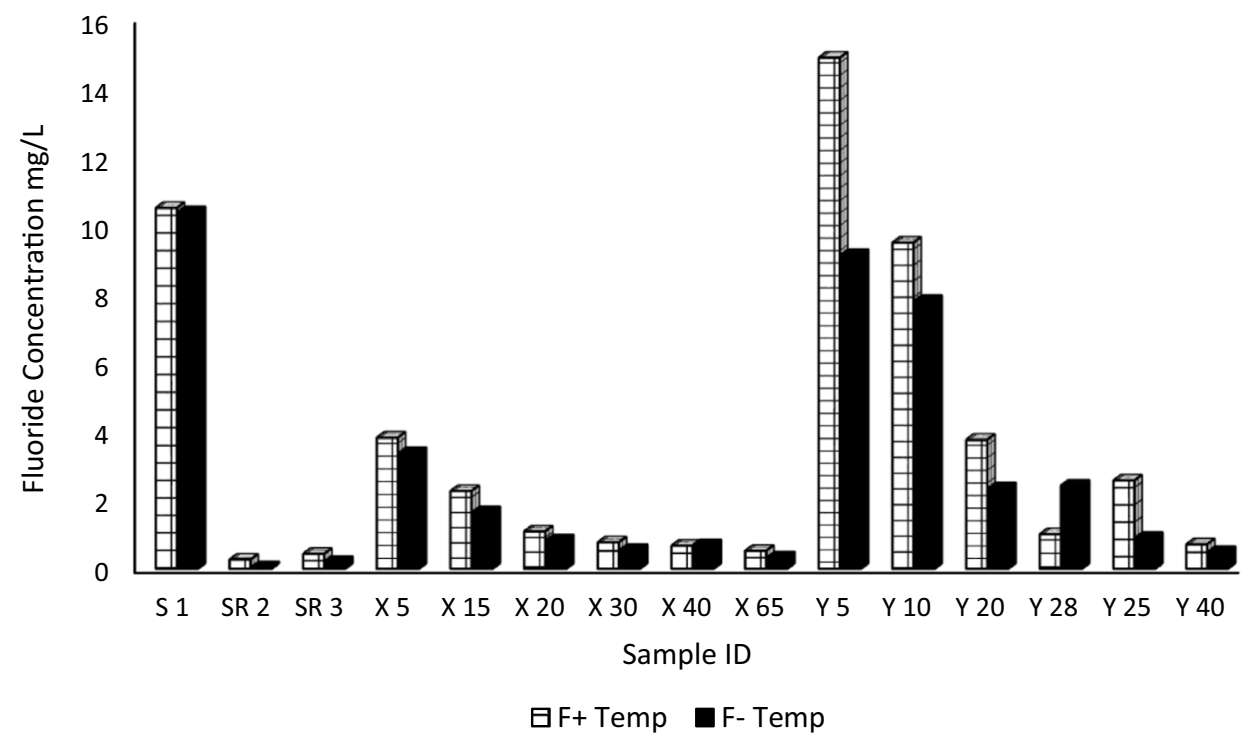

Figure 10. Fluoride leachate behaviour at room temperature and at $40{ }^{\circ} \mathrm{C}, \mathrm{F}+\mathrm{Temp}=$ Fluoride concentration at induced temperature and $\mathrm{F}-\mathrm{Temp}=$ fluoride at concentration at room temperature.

$\mathrm{NaCl}$ water type. The geological process responsible for the enrichment of groundwater is rock-water interaction and weathering. However, chemical processes activated by the rock-water interaction were identified as ion exchange and reverse ion exchange. The host minerals determined from this study are the muscovite, chlorite and smectite. The study also revealed a decreasing trend in the fluoride concentrations from the surface down to the aquifer. From the hydrogeochemical analysis, a final conclusion can be drawn that muscovite, smectite and chlorite minerals are the main contributor of fluoride to groundwater in the study area. Groundwater temperature was also determined as a major driving force for fluoride dissolution.

\section{Data availability}

The data used in this study has been included in the manuscript.

Received: 5 September 2020; Accepted: 24 June 2021

Published online: 07 July 2021

\section{References}

1. Edokpayi, J. N. et al. Challenges to sustainable safe drinking water: a case study of water quality and use across seasons in rural communities in Limpopo Province. South Africa. Water 10, 159 (2018).

2. Edokpayi, J. N., John Odiyo, J. O., Popoola, O. E. \& Msagati, T. A. M. Evaluation of contaminants removal by waste stabilization ponds: A case study of Siloam WSPs in Vhembe District. South Africa. Heliyon 7, e06207. https://doi.org/10.1016/j.heliyon.2021. e06207 (2021).

3. Enitan-Folami, A. M., Mutileni, N., Odiyo, J. O., Swalaha, F. M. \& Edokpayi, J. N. Hydrochemical, bacteriological assessment, and classification of groundwater quality in Thulamela Municipality, South Africa: potential health risk. Hum. Ecol. Risk Assess. 26(8), 2044-2058. https://doi.org/10.1080/10807039.2019.1644153 (2019).

4. Olasoji, S. O., Oyewole, N. O., Abiola, B. \& Edokpayi, J. N. Water Quality Assessment of Surface and Groundwater Sources Using a Water Quality Index Method: A Case Study of a Peri-Urban Town in Southwest, Nigeria. Environments 6, 23. https://doi.org/10. 3390/environments6020023 (2019).

5. United Nations. (2000). The Africa Water Vision for 2025: Equitable and Sustainable Use of Water for Socioeconomic Development. UN Economic Commission for Africa, P.O. Box 3001, Addis Ababa, Ethiopia. World Bank, Economic Commission for Africa, African Development Bank.

6. Abdesselam, S., Halitim, A., Jan, A., Trolard, F. \& Bourrié, G. Anthropogenic contamination of groundwater with nitrate in arid region: Case study of southern Hodna (Algeria). Environ. Earth Sci. 70, 2129-2141. https://doi.org/10.1007/s12665-012-1834-5 (2013).

7. Stellato, L. et al. Allocca V (2020) Natural and anthropogenic groundwater contamination in a coastal volcanic-sedimentary aquifer: the case of the archaeological site of Cumae (Phlegraean Fields, Southern Italy). Water 12(12), 3463. https://doi.org/10. 3390/w12123463 (2020).

8. Zereg, S., Boudoukha, A. \& Benaabidate, L. Impacts of natural conditions and anthropogenic activities on groundwater quality in Tebessa plain, Algeria. Sustain. Environ. Res. 28(6), 340-349 (2018).

9. Onipe, T. A., Edokpayi, J. N. \& Odiyo, J. O. A review on the potential sources and health implications of fluoride in groundwater of Sub-Saharan Africa. J. Environ. Sci. Health, Part A, https://doi.org/10.1080/10934529.2020.1770516 (2020).

10. Shankar S, Shankar, U \& Shikha (2014). Arsenic Contamination of Groundwater: A Review of Sources, Prevalence, Health Risks, and Strategies for Mitigation", The Scientific World Journal. vol. 2014, Article ID 304524, 18 pages, 2014.https://doi.org/10.1155/ $2014 / 304524$.

11. Yu, G. et al. The analysis of groundwater nitrate pollution and health risk assessment in rural areas of Yantai, China. BMC Public Health 20, 437. https://doi.org/10.1186/s12889-020-08583-y (2020). 
12. Ayele, B. A., Yifru, Y. M., Tekle-Haimanot, R. \& Godebo, T. R. Neuro-medical complications of fluoride toxicity among populations living in fluorosis endemic region of the Ethiopian Rift Valley. Res. Square https://doi.org/10.21203/rs.2.17675/v2 (2019).

13. Demelash, H., Beyene, A., Abebe, Z. \& Melese, A. Fluoride concentration in ground water and prevalence of dental fluorosis in Ethiopian Rift Valley: Systematic review and meta-analysis. BMC Public Health 19, 1298. https://doi.org/10.1186/s12889-0197646-8 (2019).

14. Rango, T. et al. Groundwater Quality and Its Health Impact: An Assessment of Dental Fluorosis in Rural Inhabitants of the Main Ethiopian Rift. Environ. Int. 43, 37-47. https://doi.org/10.1016/j.envint.2012.03.002 (2012).

15. Apambire, W. B., Boyle, D. R. \& Michel, M. F. Geochemistry, genesis, and health implications of floriferous groundwater in the upper regions of Ghana. Environ. Geol. 33(1), 13-24. https://doi.org/10.1007/s002540050221 (1997).

16. Fawell, J. K., Bailey, K. \& Chilton, J. Fluoride in Drinking-Water (World Health Organization, 2006).

17. Idon, P. I. \& Enabulele, J. E. Prevalence, severity, and request for treatment of dental fluorosis among adults in an endemic region of Northern Nigeria. Eur. J. Dentistry. 12, 184-190. https://doi.org/10.4103/ejd.ejd_260_17 (2018).

18. Kut, K. M. K., Sarswat, A., Srivastava, A., Pittman, C. U. Jr. \& Mohan, D. A review of fluoride in African groundwater and local remediation methods. Groundwater Sustain. Dev. 2, 190-212. https://doi.org/10.1016/j.gsd.2016.09.001 (2016).

19. Sauerheber, R. Physiologic conditions affect toxicity of ingested industrial fluoride. J. Environ. Public Health https://doi.org/10. $1155 / 2013 / 439490$ (2013).

20. Shomar, R. B., Müller, G., Yahya, A., Askar, S. \& Sansur, R. Fluorides in groundwater, soil and infused black tea and the occurrence of dental fluorosis among school children of the Gaza strip. J. Water Health 2(1), 23-35. https://doi.org/10.2166/wh.2004.0003 (2004).

21. Shen, J. \& Schäfer, A. I. Factors affecting fluoride and natural organic matter (NOM) removal from natural waters in Tanzania by nanofiltration/reverse osmosis. Sci. Total Environ. 527, 520-529 (2015).

22. Gevera, P., Mouri, H.\& Maronga, G. (2018). High Fluoride and Dental Fluorosis Prevalence: A Case Study from Nakuru Area, the Kenyan Rift Valley. Geophysical Research Abstracts. Vol. 20, EGU2018-1422, 2018. EGU General Assembly 2018.

23. Haji, M., Wang, D., Li, L., Qin, D. \& Guo, Y. Geochemical evolution of fluoride and implication for F enrichment in groundwater: Example from the bilate river basin of southern main ethiopian rift. Water 10, 1799. https://doi.org/10.3390/w10121799 (2018).

24. Rango, T. et al. Fluoride Exposure from Groundwater as Reflected by Urinary Fluoride and children's dental fluorosis in the Main Ethiopian Rift Valley. Sci. Total Environ. 496, 188-197. https://doi.org/10.1016/j.scitotenv.2014.07.048 (2014).

25. McCaffrey, L.P. \& Willis J.P. (2001). Distribution of fluoride-rich groundwater in the eastern and Mogwase regions of the Northern and North-West Provinces. WRC Report No. 526/1/01. Water Research Commission, Pretoria.www.rsc.org.

26. Olivier, J., Venter, J. S. \& Jonker, C. Z. Thermal and chemical characteristics of thermal springs in the northern part of the Limpopo Province, South Africa. Water SA 34(2), 163-174. https://doi.org/10.4314/wsa.v37i4.1 (2011).

27. Aravinthasamy, P., Karunanidhi, D., Subramani, T., Srinivasamoorthy, K. \& Anand, B. Geochemical evaluation of fluoride contamination in groundwater from Shanmuganadhi River basin, South India: Implication on human health. Environ. Geochem. Health 42, 1937-1963. https://doi.org/10.1007/s10653-019-00452-x (2020).

28. Jenifer, M. A. \& Jha, M. K. Comprehensive risk assessment of groundwater contamination in a weathered hard-rock aquifer system of India. J. Clean. Prod. 201, 853-868 (2018).

29. Jha, M. K., Shekhar, A. \& Jenifer, M. A. Assessing groundwater quality for drinking water supply using hybrid fuzzy-GIS-based water quality index. Water Res. 179, 115867. https://doi.org/10.1016/j.watres.2020.115867 (2020).

30. MacDonald, A. \&Davies, J. A Brief Review of Groundwater for Rural Water Supply in Sub-Saharan Africa. Technical Report WC/00/33. 2000.

31. Ncube, E. J. \& Schutte, C. F. The Distribution of Fluoride in South African Groundwater and the Impact thereof on Dental Health (University of Pretoria, 2002).

32. Durowoju, O. S., Butler, M., Ekosse, G. E. \& Odiyo, J. O. Hydrochemical processes and isotopic study of geothermal springs within Soutpansberg, Limpopo Province, South Africa. Appl. Sci. 9, 1688 (2019).

33. Odiyo, J. O. \& Makungo, R. Chemical and microbial quality of groundwater in Siloam village, implications to human health and sources of contamination. Int. J. Environ. Res. Public Health 15, 317. https://doi.org/10.3390/ijerph15020317 (2018).

34. Olivier, J., Van Niekerk, H. J., Van der Walt, I. J. \& Van Der Walt, I. Physical and Chemical Characteristics of Thermal Springs in the Waterberg Area in Limpopo Province. WSA. 34, 163-174. https://doi.org/10.4314/wsa.v34i2.183636 (2019).

35. Odiyo, J. O. \& Makungo, R. Fluoride concentrations in groundwater and impact on human health in Siloam, Limpopo Province. South Africa. Water SA 38(5), 731-736. https://doi.org/10.4314/wsa.v38i5.12 (2012).

36. Makungo, R., Odiyo, J. O., Ndiritu, J. G. \& Mwaka, B. Rainfall-runoff modelling approach for ungauged catchments: A case study of Nzhelele River sub-quaternary catchment. Phys. Chem. Earth, Parts A/B/C 35(13-14), 596-607. https://doi.org/10.1016/j.pce. 2010.08.001 (2010).

37. Makungo, R. (2008). The adequacy of water supply to meet the demand in Siloam of Limpopo Province of South Africa. Honours, mini-dissertation, University of Venda, Thohoyandou, South Africa.

38. Department of Water Affairs and Forestry (DWAF). (2001). Luvuvhu/Letaba water management area: Water resource situation assessment report NO P0200/00/030/. WSM (pty) Ltd. Department of Water Affairs and Forestry, Pretoria.

39. Brandl, G., Cloete, M. \& Anhaeusser C.R. (2006). Sedimentary Rocks of the Karoo Supergroup. In: Johnson M.R., van Vuuren C.J., Visser J.N.J., Cole D.I., de V. Wickens H., Christie A.D.M., Roberts D.L. (Eds). The Geology of South Africa. Geological Society of South Africa, Johannesburg/Council for Geoscience, Pretoria. pp 461-499.

40. Brandl, G. (1999). Soutpansberg Group. Catalogue of South African lithostratigraphic units. SA Committee for Stratigraphy, Council for Geoscience. pp 6.

41. South African Council of Stratigraphy (SACS). (1980). Stratigraphy of South Africa, Part 1 (Comp. L.E. Kent). Lithostratigraphy of the Republic of South Africa, South West Africa/Namibia, and the Republics of Bophuthatswana, Transkei and Venda. Handbook Geological Survey, South Africa. 8, pp 690.

42. Barker, O. B., Brandl, G., Callagham, C. C., Eriksson, P. G. \& Van der Neut, M. The Soutpansberg and Waterberg Groups and the Blouberg Formation. In The Geology of South Africa (eds Johnson, M. R. et al.) 301-318 (Geological Society of South Africa \& Council for Geoscience, 2006).

43. Johnson, M. R., Anhaeusser, C. R. \& Thomas, R. J. The geology of South Africa 301-318 (Published jointly by the Geological Society of South Africa, 2006).

44. Brandl, G. (2002). The geology of the Alldays area. Explanation sheet geological Survey South Africa, 2228 (Alldays). pp 71.

45. Harvey, D. (2000). Modern analytical chemistry. International edition. Mc Graw-Hill Company, ISBN: 0-07-116953-9.

46. Weaver, J.M., Cavé, L.C. \& Talma, A.S. (2007). Groundwater sampling: a comprehensive guide for sampling methods. Water Research Commission.

47. Pais, I. \& Jones, J. B. The handbook of trace elements (Lucie Press, 1997).

48. Onipe, T.A. (2016). Investigation of Possible Geogenic Source of Fluoride in Groundwater: A Case Study of Siloam, Limpopo South Africa. Unpublished Honours mini-dissertation, University of Venda, South Africa.

49. Onipe, T.A. (2018). Geogenic fluoride source in groundwater: A case Study of Siloam Village, Limpopo Province, South Africa. Unpublished Master's dissertation, University of Venda, South Africa.

50. Doebelin, N. \& Kleeberg, R. Profex: A graphical user interface for the Rietveld refinement program BGMN. J. Appl. Crystallogr. 48(5), 1573-1580. https://doi.org/10.1107/S1600576715014685 (2015). 
51. Thermoscientific (2011). Thermo Scientific ARL PERFORM'X XRF Sequential X-Ray Fluorescence Spectrometer. http://tools. thermofisher.com/content/sfs/brochures/D01508 .pdf.

52. SANS (2015). South African National Standards 241-1-2015; SANS: Pretoria, South Africa.

53. World Health Organisation. Guidelines for drinking-water quality world health organization IV. (WHO, 2011).

54. Kim, K. Long-term disturbance of groundwater chemistry following well installation. Groundwater 41, 780-789 (2003).

55. Kim, K. et al. The geochemical evolution of very dilute $\mathrm{CO}_{2}$-rich water in Chungcheong Province, Korea: processes and pathways. Geofluids 8(1), 3-15 (2008).

56. Tekle-Haimanot, R. et al. The geographic distribution of fluoride in surface and groundwater in Ethiopia with an Emphasis on the Rift Valley. Sci. Total Environ. 367(1), 182-190. https://doi.org/10.1016/j.scitotenv.2005.11.003 (2006).

57. Kirkpatrick, I. M. The Thermal Springs of Malawi. XXIII Int. Geol. Congress 19, 111-120 (1969).

58. Chae, G. T. et al. Fluorine geochemistry in bedrock groundwater of South Korea. Sci. Total Environ. 385, 272-283. https://doi.org/ 10.1016/j.scitotenv.2007.06.038 (2007).

59. Nezlie, I. E., Achour, S., Djidel, M. \& Attalah, S. Presence and origin of fluoride in the complex terminal of Ouargla Basin (Northern Sahara of Algeria). Am. J. Appl. Sci. 6(5), 876-881 (2009).

60. Edokpayi, J. N. et al. Recent trends and national policies for water provision and wastewater treatment in South Africa. In Water Conservation and Wastewater Treatment in BRICS Nations - Technologies, Challenges, Strategies and Policies, 978-0-12-818339-7 (eds Singh, P. et al.) 187-211 (Elsevier, 2020).

61. Fewtrell, L. Drinking-water nitrate, methemoglobinemia, and global burden of disease: A discussion. Environ. Health Perspect. 112(14), $1371(2004)$

62. Kim, K. et al. Evaluation of geochemical processes affecting groundwater chemistry based on mass balance approach: a case study in Namwon, Korea. Geochem. J. 39(4), 357-369 (2005).

63. Piper, A. M. A graphic procedure in geochemical interpretation of water analyses. Trans. Am. Geophys. Union 25, 914-923 (1944).

64. Durowoju, O. Trace element concentrations in geothermal springs and their impact on soil and vegetation in Siloam and Tshipise springs (University of Venda, 2015).

65. Gibbs, R. J. Mechanisms controlling world water chemistry. Science 170, 1088-1090 (1970).

66. Hounslow A. (1995). Water quality data: analysis and interpretation. CRC press. ISBN 0-87371-676-0, Library of Congress Card 95-48. 71 - 175. https://doi.org/10.1201/9780203734117

67. Mayback, M. Global chemical weathering of surficial rocks estimated from river dissolved loads. Am. J. Sci. 287, 401-428. https:// doi.org/10.2475/ajs.287.5.401 (1987).

68. Sajil Kumar, P. J. \& James, E. J. Physicochemical parameters and their sources in groundwater in the Thirupathur region, Tamil Nadu, South India. Appl. Water Sci. 3, 219-228. https://doi.org/10.1007/s13201-012-0074-x (2013).

69. Phillips, W.J. \& Phillips, N. (1980). An introduction to mineralogy for geologists. John Wiley \& Sons. ISBN-13: 978-0471277958. 366.

70. María, G.G. \& Laura, B. (2015). Fluoride in the Context of the Environment. Food and Nutritional Components in Focus No.6 Fluorine: Chemistry, Analysis, Function and Effects, edited by Victor R Preedy, published by the Royal Society of Chemistry.

71. Sivasankar, V., Darchen, A., Omine, K., and Sakthivel, R. 2016. Fluoride: a world ubiquitous compound, its chemistry, and ways of contamination. Chapter 2, In Surface modified carbons as scavengers for fluoride from water; $223 \mathrm{p}$ in V.Sivasankar (ed.), XIII, Springer. Doi:https://doi.org/10.1007/978-3-319-40686-2_2.

72. Liu, X., Wang, B. \& Zheng, B. Geochemical process of fluorine in soil, China. J. Geochem. 33(3), 277-279. https://doi.org/10.1007/ s11631-014-0688-9 (2014).

73. Jacks, G. \& Sharma, V. P. Geochemistry of calcic horizons in relation to hillslope processes, southern India. Geoderma 67(3-4), 203-214. https://doi.org/10.1016/0016-7061(95)00002-6 (1995).

74. Wedepohl, K. H., Delevaux, M. H. \& Doe, B. R. The potential source of lead in the Permian Kupferschiefer bed of Europe and some selected Paleozoic mineral deposits in the Federal Republic of Germany. Contrib. Miner. Petrol. 65(3), 273-281 (1978).

75. Department of Environmental Affairs (DEA). (2010). The Framework for the Management of Contaminated Land, South Africa. Available online: http://sawic.environment.gov.za/documents/562.pdf (accessed on 5 November 2017)

76. Kabata-Pendias, A. \& Pendias, H. Trace Elements Soils Plants [M] (CRC Press, 1984).

77. Lagat, J.K.E. (2007). Hydrothermal alteration mineralogy in geothermal fields with case examples from Olkaria domes geothermal field, Kenya. 001045504. Presented at Short Course II on Surface Exploration for Geothermal Resources, organized by UNU-GTP and KenGen, at Lake Naivasha, Kenya. Pp 26.

78. Durowoju, O., Odiyo, J. O. \& Ekosse, G. Hydrogeochemical setting of geothermal springs in Limpopo Province, South Africa. Res. J. Chem. Environ. 19(1), 77-88 (2015).

\section{Acknowledgements}

The contribution by Dr Durowoju and Dr Makungo for providing some site-specific data is highly appreciated.

\section{Authors contribution}

T.A.O., J.N.E. and J.O.O. conceptualized the study. T.A.O. performed the laboratory analysis, T.A.O. and J.N.E. performed the data analysis and wrote the first draft of the manuscript. All the authors contributed to the final draft of the manuscript and approved it for submission.

\section{Funding}

This research was funded by National Research Foundation of South Africa, grant numbers SFH150709124675 and UID: 127176 (Ref:RA190111407282).

\section{Competing interests}

The authors declare no competing interests.

\section{Additional information}

Correspondence and requests for materials should be addressed to J.N.E.

Reprints and permissions information is available at www.nature.com/reprints.

Publisher's note Springer Nature remains neutral with regard to jurisdictional claims in published maps and institutional affiliations. 
(c) (i) Open Access This article is licensed under a Creative Commons Attribution 4.0 International cc) License, which permits use, sharing, adaptation, distribution and reproduction in any medium or format, as long as you give appropriate credit to the original author(s) and the source, provide a link to the Creative Commons licence, and indicate if changes were made. The images or other third party material in this article are included in the article's Creative Commons licence, unless indicated otherwise in a credit line to the material. If material is not included in the article's Creative Commons licence and your intended use is not permitted by statutory regulation or exceeds the permitted use, you will need to obtain permission directly from the copyright holder. To view a copy of this licence, visit http://creativecommons.org/licenses/by/4.0/.

(C) The Author(s) 2021 